\title{
Images of Stars and their Significance in Japanese Esoteric Art of the Heian Period
}

\section{Tsuda Tetsuei}

\begin{abstract}
This essay considers the significance of images of stars within the framework of Esoteric Buddhism in the Heian Period. Firstly, it outlines the development of Heian Esoteric Art in three stages, and points at the appearance of star icons in the third stage. Secondly, it examines some representative examples of this iconography as developed by competing schools of Esoteric Buddhism: the rectangular star mandala created by the Shingon Ninna-ji school; the Sonjōō mandala created by the Tendai Jimon school; and the circular star mandala created by the Tendai Sanmon school. I discuss the similarities that occur in these representations, for example the position of stars, and reconsider the historical significance of the creation of such icons in the area of the capital from the late tenth to the early eleventh centuries. In addition, I introduce one example of unique star imagery created at the same time in the provinces.
\end{abstract}

This essay discusses images of stars in the context of the Esoteric Buddhist (i.e. Tantric) art of the Heian 平安 period. I first examine the development of Esoteric Buddhist art in Japan, and then consider the iconography of stars within that framework.

\section{The Development of Esoteric Buddhist Art in Japan and the Place of Star Images}

The Esoteric Buddhist art of Japan has traditionally been divided into two categories:

1. Eclectic esoteric (zōmitsu 雑密) art of the Nara period (eighth century);

2. Pure esoteric (junmitsu 純密) art that developed from the ninth century onwards and was shaped by the iconography of the Mandala of the Two Worlds, consisting of the Diamond World (kongōkai 金剛界) and the Womb World (taizo 胎蔵).

Eclectic esoteric images, such as those representing the bodhisattva Kannon with eleven heads (J: Jūichimen Kannon 十一面観音; Sk:

Tsuda Tetsuei, 'Images of Stars and their Significance in Japanese Esoteric Art of the Heian Period', Culture and Cosmos, Vol.10 no 1 and 2, Spring/Summer and Autumn/Winter 2009, pp. 145-192.

www.CultureAndCosmos.com 
146 Images of Stars and their Significance in Japanese Esoteric Art of the Heian Period

Ekadaś amukha-avalokiteś vara) or with thousand arms (J: Senju Kannon 千手観音; Sk: Sahasrabhuja-avalokiteś vara) or as Fukūkenjaku 不空羂索観音 (Sk: Amoghapāśa-avalokiteśvara), were produced in the capital Heijō-kyō (Nara). The Fukūkenjaku Kannon of the Tōdai-ji 東大寺 is a representative image of this category. (Fig. 1) The Records of the Treasures of Saidai-ji (Saidai-ji shizai ruki chō 西大寺資財流記帳) also documents the existence in the eighth century of a new type of image, such as the bodhisattva Makamayuri 摩訶摩由璃菩薩 (Sk: Mahāmayuri) and of the god Naraen 那羅延天 (Sk: Nārāyana) with eight arms, which no longer exist. ${ }^{1}$ They indicate a new development in the eclectic esoteric art, which occurred in the late eighth century and can be seen concretely in the multi-limbed Batō Kannon 馬頭観音 (Sk: Hayagrīva) kept at the Inanaki-dō 嘶堂 hall of the Daian-ji 大安寺 (Fig. 2 ). The fundamental characteristic of these eclectic esoteric images was their individuality: unlike the deities of pure Esoteric Buddhism, who existed within the interactive relationship of the world of the mandala (Fig. 3), earlier esoteric deities were worshipped individually with their own invocations (dhāranī 陀羅尼).

Pure esoteric art developed in and around the capital Heian (Kyoto) and was produced by both the Shingon 真言 and Tendai 天台 schools of Esoteric Buddhism. From the art history perspective, I believe we can divide it into three periods, irrespective of whether it belonged to Shingon or Tendai. The first period covers the ninth century, when images were created to follow faithfully the iconography transmitted by monks who studied in China, such as Kūkai 空海 (744-835), Saichō 最澄 (767-822), Engyō 円行 (799-852), Jōgyō 常暁 (?-866), Ennin 円仁 (794-864), Enchin 円珍 (814-891), Eun 恵運 (789-869), and Shūei 宗頻 (809-884). The second period covers the span of time from the late ninth century to the early tenth century, when the existence of a great number of sutras and esoteric ritual manuals encouraged a re-examination of the iconography of Buddhist deities, and images were made as accurately as possible to meet the specifications given in those texts. The third period goes from the late tenth century onwards, when completely new Japanese

1 The Records were edited in 780. For a list of their contents, see Nara rokudaiji taikan 奈良六大寺大観, Vol. 14 (Saidai-ji), Tokyo: Iwanami shoten, 1973, pp. 129-133.

Culture and Cosmos 
deities were created thanks to the diversification of esoteric schools. Each of the esoteric lineages developed a distinct type of imagery, validated by the personal interpretations of their leading monks, and supported by the court and aristocratic patrons. Images of stars belong to this period. However, in order to clarify the characteristics of those images, it is necessary to examine briefly some important examples of Buddhist icons from the first and second periods.

\section{Representative examples from the first two periods of Heian Esoteric Buddhist art}

I would like to consider two examples: the Nyoirin Kannon 如意輪観音 (Sk: Cintāmani-cakra) kept at Kanshin-ji 観心寺, as representative of the first period, and the Nyoirin Kannon at Daigo-ji 醍醐寺, from the second period.

The Kanshin-ji image, dating from circa 839 , is a brightly painted sculpture that retains the original colour very well ${ }^{2}$ (Fig. 4). It is thought to recreate the brilliantly colored image of Nyoirin Kannon in the Kannon-in section of the original Womb Mandala transmitted to Japan by Kūkai (Fig. 5). I would like to draw your attention to the way in which the open palm of Kannon's principal right hand touches his cheek.

The image in the Daigo-ji dates, as I have established in a previous study, from around $919^{3}$ (Fig. 6). In contrast to the Kanshin-ji image, it is lacquered in gold, and the principal right hand is shaped as a fist that touches the cheek of the bodhisattva. If we look carefully at this hand we can observe that the thumb, index and middle fingers are gently spread, and the two remaining fingers are bent (Fig. 7). The shape of this hand matches exactly the specifications given for the meditation hand (shiyuishu 思惟手) of Nyoirin Kannon in the sixteenth chapter of the

2 Nishikawa Shinji 西川新次, 'Kanshin-ji Nyoirin Kannonzō ni tsuite 観心寺如意輪観音像について' [Nyoirin Kannon of the Kanshinji Temple], Bijutsu-shi 美術史 [Art History] 23 (Tokyo: 1956), pp. 1-14.

3 Tsuda Tetsuei 津田徹英, 'Daigoji Nyoirin Kannozō kō 醍醐寺如意輪観音像考' [On the Daigoji Nyoirin Kannon], Bijutsushi 132 (1992), pp. 190- 208. 
148 Images of Stars and their Significance in Japanese Esoteric Art of the Heian Period

Commentary on the Mahāvairocana sutra, a major esoteric scripture. ${ }^{4}$ It would have not been possible to obtain such detailed information from an iconographical drawing depicting the fist from the front; hence the image must have been made according to the description in the Commentary. We should also note that, in sutras and ritual manuals related to Nyoirin Kannon, the body of this deity is described as having a golden complexion. ${ }^{5}$ The Daigo-ji image is lacquered in gold to conform to the description in the scriptural sources.

In the late ninth century and early tenth century esoteric images were frequently created to meet the instructions given in related sutras and ritual manuals. For example, the two attendant bodhisattvas of the Amida 阿弥陀 triad in the Seiryō-ji 清凉寺 (Kyoto) are represented forming unusual hand gestures (mudrā $s$ ), the source of which has never been clear (Fig. 8). I have identified these hand gestures as the katsuma mudrā 羯磨印 of two bodhisattvas described in a ritual manual related to the esoteric Amida. ${ }^{6}$ These two bodhisattvas, Kongōhō 金剛法菩薩 and Kongōri 金剛利菩薩 are, in fact, the esoteric interpretation of Kannon and Seishi (Sk: Mahāsthamaprāpta). ${ }^{7}$ Such an attitude towards the creation of Buddhist images reflects the confusion caused by the flood of information introduced by monks who had studied in China. As the details of the hands often varied, when new images were made it became necessary to consult related sutras and ritual manuals. Another example of a detail that would have been difficult to copy from a diagram, as this

4 Da pilushena chengfo jingshu (J: Daibirushana jōbutsu kyōsho 大毘盧舎那成仏経疏), Taishō shinshī daizōkyō 大正新脩大蔵経, Tokyo: Taishō shinshū daizōkyō kankō-kai, 1928 (hereafter cited as T.), 39, p. 744a-c.

5 These are Guanzizai pusa ruyilun yuqie (J: Kanjizai bosatsu nyoirin yuga 観自在菩薩如意輪瑜伽), T. 20, p. 208c; Guanzizai ruyilun pusa yuqie fayao (J: Kanjizai nyoirin bosatsu yuga hoyō 観自在如意輪菩薩瑜伽法要), T. 20, p.

213b; and Ruyilun pusa guanmenyizhu mijue (J: Nyoirin bosatsu kanmon gichū hiketsu 如意輪菩薩観門義註秘訣), T. 20, p. $217 \mathrm{a}$.

6 Jingangding lianhuabu xin niansong yigui (J: Kongōchō rengebu shin nenju $g i k i$ 金剛頂蓮華部心念誦儀軌), T. 18, p. 305b.

7 Tsuda Tetsuei, 'Daigoji Nyoirin Kannozō kō.' 
would show the image only frontally, is the wisdom-fist mudrā (chiken-in 智拳印) of the Buddha Dainichi 大日 (Sk: Mahāvairocana), dating from the late ninth century, and kept at the Ueno-an-ji 上野庵寺 in Shiga Prefecture (Fig. 9). The index finger of the Buddha's left hand touches the tips of the thumb and the index finger of his right hand. This is an unusual detail that can be traced back only to descriptions in canonical sources.

In the case of the Kanshin-ji sculpture, which belongs to the first period of Heian esoteric artefacts, the figure reproduces the existent iconography faithfully, but the sense of movement is severely restricted in order to keep the original form. On the other hand, the Daigo-ji sculpture required a re-adjustment of the angle of the neck, and even the curve of the upper body, in order to shape its fist touching the cheeks according to the specification of the canonical sources. This affected the sculptural space. Furthermore, the position of five of the other arms was adjusted to balance the arm in the meditation pose, and our eyes are drawn to the second right hand, which holds a wish-fulfilling jewel (nyoi hojju 如意宝珠) in front of the bodhisattva's chest. Such freedom of expression became the mainstream movement in tenth century sculpture.

I would like to point out that in the tenth century a process of reexamination of established iconography was carried out, whereby the iconography transmitted, for instance, by Kūkai in the Shingon sect or by Enchin in the Tendai sect, was reconsidered against the descriptions of the deities contained in sutras and commentaries. This corresponded to a process of conscious interpretation and selection operated by image makers. The movement to consult existent iconography and canonical sources not only encouraged a partial alteration of the imagery as it had been known so far; it also, eventually, developed into the creation of images of new Japanese deities. The icons of stars clearly indicate this movement, which characterized the third period of esoteric art.

\section{The Emergence of Star Images in Japanese Buddhist Art}

Images of stars had already been created in the Nara period. We can find evidence of the existence of an image of the bodhisattva Myōken 妙見菩薩 (Sk: Sudrs $t$ i), the personification of the Polar Star, in the section on the Commission of Buddhist sculptures (Butsuzō saishiki chümon 仏像彩色注文) of the Records of the Shōsōin temple (Shōsōin 
150 Images of Stars and their Significance in Japanese Esoteric Art of the Heian Period

monjo 正倉院文書). ${ }^{8}$ The Historical Documents of Enryaku-ji (Eigaku $y \bar{o} k i$ 濬又岳要記) mentions that there was an image of Myōken, created by the founder of the Tendai school, Saichō, in the Hachibu-in 八部院 hall of the Enryaku-ji temple. ${ }^{9}$ It is not clear what these images looked like, as only their names appear in written records. However, the encyclopedia of Buddhist icons Zuzōshō 図像抄, edited by Ejū 恵什 (1060-1145), describes a contemporary icon in the Myōken-dō of the Reigen-ji 霊㛜寺 (Kyoto): it was a life-size wooden statue, holding a wish-fulfilling jewel on his left palm in front of his chest, and with his right hand stretched down with the five fingers extended, rather similar to the iconography of Kichijō-ten 吉祥天 (Sk: Mahāśrī). ${ }^{10}$ Another example of early representations of the Polar Star may be found in the Jigokudani 地獄谷 cave of Kasugayama 春日山, Nara. This carved image of a bodhisattva seated on the lotus leaf can be identified as Myōken from the constellation of the Big Dipper depicted above his head. As these examples suggest, until the late eighth century images of stars were mostly personifications of the Polar Star, but the iconography was not yet standardized, probably because it was not specified clearly in scriptures.

Individual images of stars appear not to have been standardized in the Esoteric art of the Heian period either. A prominent characteristic of this period would be the creation of group images of celestial bodies.

\section{Images of Stars from China}

The creation of original images of stars in Heian esoteric Buddhism started around the late tenth century, but it is important to remember that new information and iconographies had been brought into Japan by the monks who studied in China during the ninth century. Images of the Three Luminous Celestial Children (sankō tenshi 三光天子, i.e., sun, moon and stars) and of the twenty-eight Lunar Mansions (nijūhachi shuku 二十八宿) are mentioned in the list of items brought back by the monk

8 Dai Nihon komonjo 大日本古文書, Vol. 12, Tokyo: Tokyo daigaku shiryō hensanjo, p. 256.

9 Gunsho ruiju 群書類従, Vol. 15, Tokyo: Keizai zasshi sha, 1906, p. 556.

10 T. zuzō 3, p. 52b.

Culture and Cosmos 
Jōgyō ${ }^{11}$ together with some styles of altar for the goma 護摩 (fire) ritual. The list of items imported by Ennin includes a drawing of the altar for the Blazing Light ritual (shijōko danzu 嬂盛光壇図), the liturgy dedicated to the Blazing Light Buddha, who in Japan would embody the Big Dipper ${ }^{12}$ (Fig. 10). We also find a Butsugen Mandala, where the Nine Luminaries are depicted around the main deity Butsugen (Sk: Buddhalocanī), in an unofficial record of items brought by Enchin, ${ }^{13}$ while a note in a later iconographic manual informs us that a drawing of Nyoirin Kannon with the constellation of the Big Dipper (Shichisei Nyoirinzu) (Fig. 11) was imported by Eun. ${ }^{14}$ The existence of these records shows the interest that monks had in images of stars. There also exist several examples of star related icons of unknown provenance, which must have been brought to Japan by the mid-tenth century. Such are the Shūnanzan Mandala 終南山曼茶羅 (Fig. 12), the images contained in the Secret Calendar of the Nine Luminaries (Kuyō hireki 九曜秘暦), a Diagram of Indian Horoscopy (Bonten karazu 梵天火羅図), a similar diagram called Karazu 火羅図 (Fig. 13), and the Big Dipper Mandala in the museum collection of the National University of Fine Arts and Music in Tokyo.

Nevertheless, the development of images of stars in the Heian period did not conform to the eighth century tradition of representation, nor did Heian artists simply reproduce the iconographies transmitted in the ninth century. It was a new development that took place in Japan, based upon previously introduced material. I would like now to discuss some concrete examples of this trend.

\section{Japanese Star Mandalas}

\section{The Rectangular Star Mandala of the Shingon Ninna-ji School}

The earliest known example of an original visual representation of stars

11 Jōgyō oshō shōrai mokuroku 常暁和尚請来目録, T. 55, p. 1070c-1071a.

12 Nittō shingu shōgyō mokuroku 入唐新求聖教目録, T. 55, p. 1084c.

13 See the colophon of Goma ro danyō, T. zuzō 7, p. 840; and Annen's (841-ca 915) Sho ajari shingon burui sōroku 諸阿闍梨真言部類惣録, T. 55, p. $1131 \mathrm{~b}$.

14 Jōjin 定深 (? -1119), Sho kannon zuzō 諸観音図像, T. zuzō 12, pp. 10331034. 
152 Images of Stars and their Significance in Japanese Esoteric Art of the Heian Period

made in Japan is a star mandala used by Kankū 寛空 (884-972), a Shingon monk of the Ninna-ji lineage, for a ritual performed at the imperial palace. Unfortunately this mandala does not survive today, and we have only simplified reproductions inscribing the seed-letters of the deities in two twelve century texts, Genpishō 玄秘鈔 ${ }^{15}$ and Shike zuzōshō 四家図像鈔. ${ }^{16}$ (Fig. 14) It should be noted, though, that the image used by Kankū encouraged the development of various star mandalas.

Kankū's star mandala had a rectangular structure with three concentric sections called in (courts). The Buddha Śākyamuni of the Golden Wheel (Shaka Kinrin 䣋迦金輪; Sk: Buddhosnīsa-cakra) was placed in the middle of the central court, surrounded by the Constellation of the Big Dipper and Saturn (Doyō 土曜; Sk: Śanaiścara). The twelve signs of the zodiac were placed in groups of three at the four corners of this first court. In the second court we find eight of the Nine Luminaries collectively known as Kuyō 九曜 (Sk: Navagraha): the sun (Sk: Āditya), the moon (Sk: Soma), the five major planets Jupiter (Mokuyō 木曜; Sk: Brhaspati), Mars 火曜 (Kayō; Sk: Angāraka), Saturn, Venus (Kinyō 金曜; Sk: Sukra) and Mercury (Suiyō 水曜; Sk: Budha); and the two stars Rāhu (Ragō 羅睺), which was thought to cause the solar and lunar eclipses, and Ketu (Keitō 計都), the comet. As we have seen, the fifth planet, Saturn, was placed in the central section. The third outermost court featured the Twenty-eight Lunar Mansions, that is, the twenty-eight stars where the moon rests each night while completing its circuit in twenty-eight days. A star mandala with such a structure has no Chinese precedent, and therefore it should be considered as a Japanese creation.

The central allocation of the Sākyamuni of the Golden Wheel and the fact that this mandala was used for a ritual to pray for the well-being of the emperor suggest that the creator of this icon was aware of the Blazing Light (Shijōkō 熾盛光) Mandala. The latter had been imported from China by Ennin in the mid-ninth century and had been used as the main icon of the homonymous secret ritual (shijōkōho 熾盛光法), performed in the Tendai school for the same purpose. The Blazing Light Mandala was circular, with Śăkyamuni of the Golden Wheel in the centre, surrounded by numerous deities including the zodiac and the Twenty-eight Lunar

15 T. 78, p. 414a.

16 T. zuzō 3, p. 902.

Culture and Cosmos 
Mansions. Some scholars assume that Kankū's rectangular mandala evolved from the Blazing Light Mandala under its direct influence, ${ }^{17}$ but I believe that this was not the case. The Blazing Light ritual was one of the most important secret liturgies jealously guarded in the Tendai school, and it is most unlikely that a monk from another school could gain detailed knowledge of the iconography of its main icon. The information available to outsiders would probably have been limited to the fact that it centred on Śăkyamuni of the Golden Wheel. ${ }^{18}$

According to the explanatory notes included with the diagrams of Kankū's mandala in Genpishō and Shike zuzōshō, the arrangement of the Twenty-eight Lunar Mansions in the outer court followed the instruction of a sutra, the Kongque jing (Jap: Kujakukyo 孔雀経). ${ }^{19}$ In fact in the mandala groups of seven stars are placed at the four sides of the outer court, and the composition of each group as well as the arrangement conform to the description in the Kongque jing. Consequently, when one faces the mandala, the cardinal directions will be: east on the right, west on the left, north at the top, and south at the bottom. The arrangement of the five planets in the central and second courts matches the yin-yang theories of a fundamental Onmyōdō 陰陽道 text, the Gogyō taigi 五行大義: ${ }^{20}$ Jupiter is in the east, Venus in the west, Mars in the south, Mercury in the north, and Saturn in the centre. The planets are thus placed in the relevant directions as determined by the Twenty-eight Lunar mansions. The arrangement of the Nine Luminaries and the Twenty-eight Lunar Mansions can therefore be worked out without any direct influence from the Blazing Light Mandala. Rather, I think that the arrangement of

17 Takeda Kazuaki 武田和昭, 'Hokuto mandara no seiritsu to tenkai 北斗曼茶羅の成立と展開, [On the Establishment and Development of the Big Dipper Mandala], Mikkyō zuzō 密教図像 [Iconography of Esoteric Buddhism] 11 (Kyoto: 1992) pp. 13-34; and Hoshi mandara no kenkyu 星曼茶羅の研究 [Studies in Star Mandalas], Kyoto: Hōzōkan, 1995, pp. 77-104.

18 Hayashi On 林温 shares my view in his Myōken bosatsu to hoshi mandara 妙見菩薩と星曼茶羅, Nihon no bijutsu 日本の美術 [Japanese Art] 377 (1997), pp. 61-62.

19 The full title is Fomu da kongque mingwang jing (J: Butsumo daikujaku myōō $k y \bar{o}$ 仏母大孔雀明王経), T. 19, pp. 436c-437a.

20 Gogyō-taigi kō-chū, Tokyo: Kyūko shoin, 1984.

Culture and Cosmos 
154 Images of Stars and their Significance in Japanese Esoteric Art of the Heian Period

Saturn in the central court, in front of the Buddha of the Golden Wheel, with the other eight celestial bodies surrounding the Buddha in the second court, reflects other Chinese images of the Buddha of the Blazing Light and the nine planets, such as the one shown in Figure $15 .^{21}$

The most important feature of the rectangular star mandala is the combination of the Buddha of the Golden Wheel, Saturn, and the constellation of the Big Dipper in the central court. The recognition of these three as the central elements of the structure of a star mandala will not essentially change in subsequent icons. The presence of Saturn in this group has not been sufficiently noted, though. In the rectangular star mandala, Saturn and the seven stars of the Big Dipper are placed around the Buddha of the Golden Wheel in a manner similar to the eight-petalled lotus that constitutes the central court of the Womb Mandala (Fig. 16). This arrangement, as well as the four-cornered shape, suggests a conscious borrowing from the Womb Mandala.

\section{The Sonjōō Mandala of the Tendai Jimon School}

Following the creation of this rectangular star mandala in the Ninna-ji lineage of the Shingon school, a Sonjōo Mandala 尊星王曼茶羅 was created by the Tendai Jimon 寺門 school, based at Onjō-ji 園城寺 (Miidera 三井寺). The oldest example of this mandala is a monochrome drawing recorded in the twelfth century collection of esoteric iconography Besson zakki 別尊雑記, edited by Shinkaku 心覚 (1117-80) (Fig. 17). The drawing shows various stars and constellations placed in three concentric circles and, in the centre, a four-armed bodhisattva standing on his left leg on the back of a dragon. His right leg is bent, with his foot pulled up to the back of his left knee, making the shape of the number 4 . This is the deity called Sonjōō in the Jimon school.

The Sonjōō Mandala is also a Japanese creation. ${ }^{22}$ According to esoteric documents compiled during the Heian and Kamakura periods, Sonjōō was regarded as the deity of the Polar Star, and was also identified with Kannon and Mercury. This information provides us with some clues

21 Editor's note. On this imagery see the essay by Lilla Russell-Smith in this volume.

22 Tsuda Tetsuei, 'Jimon no sonjōō o megutte 寺門の尊星王をめぐって' [On the Depiction of Sonjōō in the Jimon Lineage of Tendai Buddhism], Museum (Bimonthly Magazine of the Tokyo National Museum) 581 (2002), pp.17-37. 
to understanding the development of Sonjōō. The first concrete evidence for a ritual involving this deity can be found in the diary of the aristocrat Fujiwara no Kōzei 藤原行成, Gonki 権記. In the entries for the third day of the third month of 1006 and for the twenty-fourth day of the third month in 1008 , the ritual is recorded as 'sonjōkōhō'. 尊星光法. ${ }^{23}$ It is important to note that the name 'sonjō kōhō' is similar to the shijōkōhō of the Tendai Sanmon 山門 school. Considering that the Sonjōō Mandala was the main icon of a ritual aimed at the well-being and longevity of the emperor just as the shijoksoho did, and that its emergence coincided with the split of the Tendai denomination in the two schools, Sanmon and Jimon, it may be possible that the Sonjōō Mandala was created by Jimon clerics to stand against the ritual of the Sanmon school. I speculate that the most likely creator of the mandala is Yokei 余慶 (919-991), a powerful monk of the Jimon school of that time.

I would like to examine next the history of the iconographical development of the Sonjōō Mandala, from a diagram which was produced in China during the Tang Dynasty (Fig. 18). The arrangement of stars in three concentric circles seems to reflect the pattern of a representation of the night sky in the northern hemisphere. This depicts all the constellations around the Polar Star, placed at the center of the diagram. We have seen that the deity in the centre of the Sonjōo Mandala (Fig. 19) is regarded as the personification of the Polar Star. However, Sonjōō does not possess the iconographic characteristics of the Polar Star alone. The iconography for the four-armed bodhisattva standing on a dragon, with his right leg making the shape of number 4, appears to originate from an image of Mercury seated on a dragon with one pendant leg, as depicted in a Butsugen mandala. (Fig. 20) This mandala was brought to Japan by the founder of the Jimon school, Enchin. The iconographical similarity can explain why Sonjōō could be identified with Mercury. In addition, Sonjōō was also identified with Kannon. We should note that the figure holding up the sun and the moon in his hands, with the remaining two hands in front of his chest, is similar to some Chinese representations of Kannon from the Song dynasty, such as a painting in the collection of the Boston Museum of Art which shows the bodhisattva seated with his left leg pendant (Fig. 21). Both these representations of Mercury and Kannon are seated figures with their left

23 Zōho shiryō taisei 増補史料大成, Gonki Vol. 1, Kyoto: Rinsen shoten, 1975, p. 53 and p. 98 . 
156 Images of Stars and their Significance in Japanese Esoteric Art of the Heian Period

legs pendant. Sonjōō takes a similar posture, but he stands on one leg. The significance of this leg may be traced back to the $u h o$ 禹歩, the ritual steps which were used in Onmyōdo, and were shaped after the constellation of the Big Dipper. My conclusion is that the iconography most likely derives from the seated Mercury and Kannon, but the pendant left leg was re-interpreted in Japan as representing a $u h o .{ }^{24}$ In this way Sonjōō possessed the characteristics of Mercury and Kannon, as well as those of the Polar Star.

I also believe that the arrangement of Sonjōo in the centre of the mandala with eight circles representing suns and moons depicted in the outermost court reflects an Onmyōdō theory concerning Saturn, according to which this planet is surrounded by eight stars. We should note a possible influence of the representation of the Diagram of Indian Horoscopy or Myōken mandala, which was devised from that theory (Fig. 22). The attributes held by Sonjōō in front of his chest, a metal staff and a three-pronged weapon, are also identical to the attributes of Saturn (Fig. 23). The animal head in Sonjōō's hairdress seems to have lost its original identity after repeated copying, and it appears in the drawing as a boar or a deer, but it may originally have been a bull, the designated head ornament for Saturn. The eight suns and moons depicted in the outermost court, too, may have been an adaptation of the eight planets that, together with Saturn, form the Nine Luminaries, as I have discussed above.

\section{The Circular Star Mandala of the Tendai Sanmon School}

The star mandala of the Ninna-ji school and the Sonjōo Mandala of the Jimon school encouraged the emergence of another star mandala: a circular star mandala created by the Tendai Sanmon school. Kakuzenshō 覚禅鈔, the ritual collection edited by Kakuzen 覚禅 (1143-?), records a note by the Sanmon monk Kakujin 覚尋 (1012-81), which clearly identifies the Tendai head-abbot Keien 慶円 (949-1019) as the creator of the circular star mandala. ${ }^{25}$ One of the most famous surviving examples

24 Tsuda Tetsuei, 'Uho, henbai to Sonjōō, Rokuji myōō no zuzō 禹歩・反開と尊星王・六字明王の図像’ [On the Iconography of Sonjōō and Rokuji Myōō and the ritual Onmyōdō steps uho and henbai], Nihon shūkyō bunkashi kenkyū 日本宗教文化史研究 [Journal of Japanese Religious and Cultural History] 4 (Kyoto: 1998), pp. 75-83.

25 T. zuzō 5, p. 402b. 
of this mandala is a painting from the twelfth century in the collection of the Hōryū-ji 法隆寺 (Fig. 24). The structure features four concentric circles: the Buddha Śakyamuni of the Golden Wheel is in the central court, seated on a rock pedestal supported by two twisting dragons; the seven stars of the constellation of the Big Dipper and the Nine Luminaries are inscribed in the second court; the zodiac is in the third court; and the Twenty-eight Lunar Mansions in the fourth court.

We can surmise that the circular star mandala was adapted from the Blazing Light Mandala, since a later ritual collection of the Sanmon school, the Asabasho 阿娑縛抄, edited in mid-thirteenth century, records that the main deity of the Blazing Light Mandala, the Buddha Śăkyamuni of the Golden Wheel, is stylistically identical to that of the circular star mandala. According to that description, the Buddha is seated on Mt. Sumeru, in front of which spreads the ocean with two dragon kings, while the sun and the moon are depicted at the sides of the Buddha. ${ }^{26}$ The circular structure also seems to follow that of the Blazing Light Mandala. If we look at the second court, the constellation of the Big Dipper is arranged in the upper section, while the Nine Luminaries are arranged in the lower section, with Saturn placed in the middle (Fig. 25). The position of Saturn in the center must be influenced by the Onmyōdo theory mentioned previously. The cardinal directions can be recognized from the zodiac sign of Leo (J: Shishi 獅子; Sk: Simha), which is placed at the top. According to a thirteenth century text, the Byakuhō kushō 白宝口抄, South is at the top and consequently North is at the bottom; the constellation of the Big Dipper is said to occupy an immovable position above the southern continent (Jambudivpa). ${ }^{27}$ This may explain the allocation of the constellation of the Big Dipper above the Buddha, in the southern direction. Previous research has proved that the iconography of the Nine Luminaries derives from the instructions contained in the Kuyo hireki, while the iconography of the Twenty-eight Lunar Mansions is borrowed from a text on fire ritual altars, Gomaro danyo.$^{28}$ It seems thus that in the creation of the circular star mandara the iconography of each group of stars was adopted from existing models.

26 T. zuzō 9, p. 25c.

27 T. zuzō 7, p. 302c.

28 Takeda Kazuaki. Cf. Note 17. 
158 Images of Stars and their Significance in Japanese Esoteric Art of the Heian Period

\section{Another Rectangular Star Mandala of the Shingon Ninna-ji School}

Slightly later than the three types of star mandala described above, another rectangular star mandala was created in the Shingon Ninna-ji school by Kanjo 寛助 (1057-1125). ${ }^{29}$ A representative example of this type is that of the Kumeta-ji 久米田寺 in Osaka, which dates from the second half of the twelfth century. (Fig. 26) This mandala follows the three-layered rectangular structure that was devised by Kankū; yet the overall composition is more reminiscent of the circular star mandala created in the Tendai Sanmon school, with the only difference being the rectangular framework. The Buddha Sākyamuni of the Golden Wheel is in the center, seated on Mt. Sumeru, which stands on two twisting dragons; the constellation of the Big Dipper and the Nine Luminaries are inscribed in the central court, the Zodiac in the second court, and the Twenty-eight Lunar Mansions in the third court. Attention should be drawn to the central court, where the sun and the moon from the group of Nine Luminaries are placed on either side of the Buddha. This arrangement is similar to the circular mandala, and furthermore seems to derive from the Blazing Light Mandala. We should also note that the seven stars of the constellation of the Big Dipper are placed directly under the Buddha. This is the opposite of the arrangement of the circular star mandala, and it is a consequence of the allocation of the zodiac sign of Leo at the center of the lower section of the second court, indicating the southern direction. Accordingly, the five planets are arranged with Venus in the east, on the left side of the central court; Mars in the west, on the right hand side; Mercury in the north, at the top; Jupiter in the south, at the bottom; and Saturn directly under the Buddha Śâkyamuni. (Fig. 27) Saturn is situated next to Sākyamuni in order to assume the central position. This arrangement suggests a stronger awareness of Onmyōdō theories than that expressed in the circular star mandala. Although the iconographic details of each of the Nine Luminaries and of the Twenty-eight Lunar Mansions may be found in the texts mentioned above, the Kuyo hireki and the Gomaro danyō, it is more likely that, rather than copying from the instructions contained in these manuscripts, the Kumeta-ji mandala had its iconographic source in the circular star mandala. The iconography for the constellation of the Big Dipper, too, seems to rely heavily on the circular star mandala. Therefore the

29 T. zuzō 7, p. 302c.

Culture and Cosmos 
rectangular star mandala created by Kanjo followed the basic structure of Kankū's rectangular star mandala, while the arrangement of the deities relied on the circular star mandala of the Tendai Sanmon school. It could be said that it lacked originality.

Interestingly, on the twenty-seventh day of the second month of the year 1109 a hall dedicated to the Polar Star was consecrated in the Hosshō-ji 法勝寺 in Kyoto. It was commissioned by the retired emperor Shirakawa 白河, and a large group of wooden images, representing the fifty-six figures of the star mandala, was created. ${ }^{30}$ As the chief priest presiding over the ceremony was Kanjo, we may suppose that the images were based on the rectangular star mandala created by him. ${ }^{31}$ It is easy to imagine that, in comparison to a painting, a three-dimensional mandala with a large number of wooden images was overwhelmingly impressive. However, the individual sculptures must have been relatively small in order to fit into the limited space of that hall.

From this material, we can say that the enthusiasm for visual images of stars peaked from the second half of the tenth century to the early eleventh century. Both Shingon and Tendai sects emphasized their distinctive features, which resulted in the creation of the rectangular star mandala by Kankū, the Sonjōō Mandala by Yokei, and the circular star mandala by Keien. The emphasis on individuality coincided with the contemporary diversification of the esoteric schools in various branches. The creation of images was probably a means for each school to show the superiority of its ritual power to the court and aristocracy. ${ }^{32}$

\section{A local development of star imagery in the provinces}

It is often overlooked that unique visual representations of stars emerged at the same time in the provinces. One such example is a secret Buddhist image (hibutsu 秘仏) kept at Tōkō-in 東光院 in Chiba Prefecture. It

30 Gō totoku nagon ganmon shū 江都督納言願文集, Tokyo: Shibundō, 1929, pp. 41-43.

31 Kurimoto Tokuko 栗本徳子, 'Shirakawa-in to Ninna-ji 白河院と仁和寺, [Retired Emperor Shirakawa and the Ninna-ji], Kanazawa bunko kenky $\bar{u}$ 金澤文庫研究 286 (Yokohama: 1991), pp. 12-30.

32 Tsuda Tetsuei, 'Rokuji myōō no shutsugen 六字明王の出現' [Emergence of Rokuji Myōō], Museum 553 (Tokyo: 1998), pp. 27-54. 
160 Images of Stars and their Significance in Japanese Esoteric Art of the Heian Period

comprises seven sculptures, which are said to represent the constellation of the Big Dipper, and are also identified with the seven Yakushi nyorai 薬師如来 (Sk: Bhaiș ajyaguru-vaidūryaprabha) (Fig. 28). The set consists of a larger than life-size Buddha and six life-size bodhisattvas. Two of the bodhisattvas have a Buddha's head on the top of their crown, a very unusual iconographic feature that is not recorded in any esoteric manual. Although the crystal eyes of the main Buddha were added in a later period when the sculpture was restored, the style of the sculptures indicates that they were created as a set of seven in the early eleventh century, before the area was devastated by the rebellion headed by Taira no Tadatsune 平忠常 in 1028. Considering the substantial economic means needed for the creation of life-size figures, it is fair to assume that the set of seven figures was commissioned by a provincial lord. In fact, textual references suggest that they were used as the main object of worship of the Hirayama-ji 平山寺 temple, as the Tōkō-in was originally called, which was commissioned by Taira no Tsunemasa 平常将, a son of the provincial lord Taira no Tadatsune. ${ }^{33}$

The significance of these seven figures lays in their unique group composition. A detailed examination of the six bodhisattvas reveals that three of them are seated cross-legged with their right foot on top, while the other three have the left foot on top. Each group of three includes two figures with a crowned head and one figure with a Buddha's head above their crown. Their hand gestures are basically similar to those of the main Buddha, with the thumb touching the middle finger. The fact that the bodhisattvas are not holding any attribute but form mudrās suggests that they are esoteric Buddhist images. Yet when we consider that canonical esoteric Buddhist figures should be seated with the left foot placed under the right knee, ${ }^{34}$ we cannot categorize the entire group as esoteric in the

33 Tsuda Tetsuei, 'Chiba Tōkō-inzō den shichi butsu Yakushi zazō no zuzō hyōgen o megutte 千葉・東光院蔵 伝七仏薬師坐像の図像表現をめぐって’ [On the iconography of the seated statues traditionally identified as Seven Bhaisajyaguru, held at Tōkō-in, Chiba Prefecture], Mikkyō zuzō 12 (1993), pp. 21-43. Apart from this set, the temple also holds two sculptures of Guardians from the same, or immediately successive, period. See Fig. 29.

34 For the meaning of sitting with the left foot placed under the right knee in Esoteric Buddhist Art, see Oku Takeo 奥健夫, 'Tōji den shōsō monjuzō o megutte 東寺伝聖僧文殊像をめぐって’ [On the Shōsō Statue of Manjusri in Tō-ji], Bijutsu-shi 134 (1993), pp. 169-170.

Culture and Cosmos 
strict sense, because some figures have their left foot on top.

I believe that the composition of this group, with a seated Buddha image and six seated bodhisattvas, may be a reflection of the Rokujikyō Mandala 六字経曼茶羅, which depicts Śākyamuni of the Golden Wheel surrounded by six Kannon. (Fig. 30) When we consider that in the eleventh century Yakushi was identified with Sākyamuni of the Golden Wheel in both the Shingon and Tendai sects, ${ }^{35}$ it is possible to recognize a relationship between the Sākyamuni with six Kannon of the Rokujikyō Mandala and the seven figures of the Tōkō-in temple. Furthermore, at that time the seven stars of the Big Dipper were interpreted as a manifestation of the seven Yakushi, ${ }^{36}$ and six of the stars were identified with Kannon. ${ }^{37}$ However, there are differences in the attributes and the position of arms and legs between the Tōkō-in group and the deities of the Rokujikyō Mandala. All six bodhisattvas of the Tōkō-in make a $m u d r \bar{a}$ with the thumb and middle fingers, which is associated to the constellation of the Big Dipper according to a Chinese manual for the Big Dipper fire ritual. ${ }^{38}$ In the iconographic collection Zuzossho, this hand gesture is commonly recognized as a $m u d r \bar{a}$ of Yakushi. ${ }^{39}$ Bearing these facts in mind, we can assume that the seven figures of the Tōkō-in temple represent the seven Yakushi as the manifestation of the stars of the Big Dipper. This sculptural group should not be ignored, since it represents a unique achievement in the creation of star images in the provinces of the

35 See Shingon senzin zuimonki 真言深浅随聞記 vol. 2 (the manuscript held at the museum of Kanazawa bunko was copied, according to its colophon, in 1092); and Chōen's 長宴 (1016-1081) Shijūchō ketsu 四十帖決 vol. 7, T. 75, p. $877 \mathrm{~b}$.

36 Beidou qixing yanming jing (J: Hokuto shichisei enmei kyō 北斗七星延命経), in T. 21, p.426a; Kanjo (1057-1125) ed., Betsu gyo 別行, in T. 78, p. 182 b.

37 Cf. Betsu gyō.

38 Beidou qixing humofa (J: Hokuto shichisei gomahō 北斗七星護摩法), T. 21, pp. 457c-458a.

39 Beidou qixing humofa (J: Hokuto shichisei gomahō 北斗七星護摩法), T. 21, pp. 457c-458a. 
162 Images of Stars and their Significance in Japanese Esoteric Art of the Heian Period

time. Nevertheless, the position of the arms and the mudrās of all the six bodhisattvas are identical. This lack of individual features makes it difficult to identify the names of each deity, and it points to the creative limitations of esoteric images. No similar figures were made after this prototype. ${ }^{40}$

\section{Concluding remarks}

In this article, I have divided Heian esoteric Buddhist art into three periods, and treated the images of stars as typical examples from the third period, when entirely new icons were created in Japan. I have examined the development of several representative works, with reference to surviving manuscripts on iconography, sutras and ritual commentaries. It is a fact that images of stars did not become the principal icon of any major school of Buddhism, but they were valued as the focus of rituals that served to promote the individuality and superiority of each branch of Esoteric Buddhism when its diversification took place.

The individuality of the images of stars in Japan relied heavily on the arbitrary interpretation of the monks who initiated specific projects. The enthusiasm for new creations reached its peak between the tenth and eleventh centuries, but never developed into a major current of esoteric Buddhist art. The number of related masterpieces is limited too, and I believe that their transient nature symbolizes the limitations and the fate of Japanese creations connected to the stars.

(Translation by Meri Arichi)

40 T. zuzō 3, p. 6c.

Culture and Cosmos 
Tsuda Tetsuei 163

Fig. 1 Fukūkenjaku Kannon. Tōdai-ji, Nara.

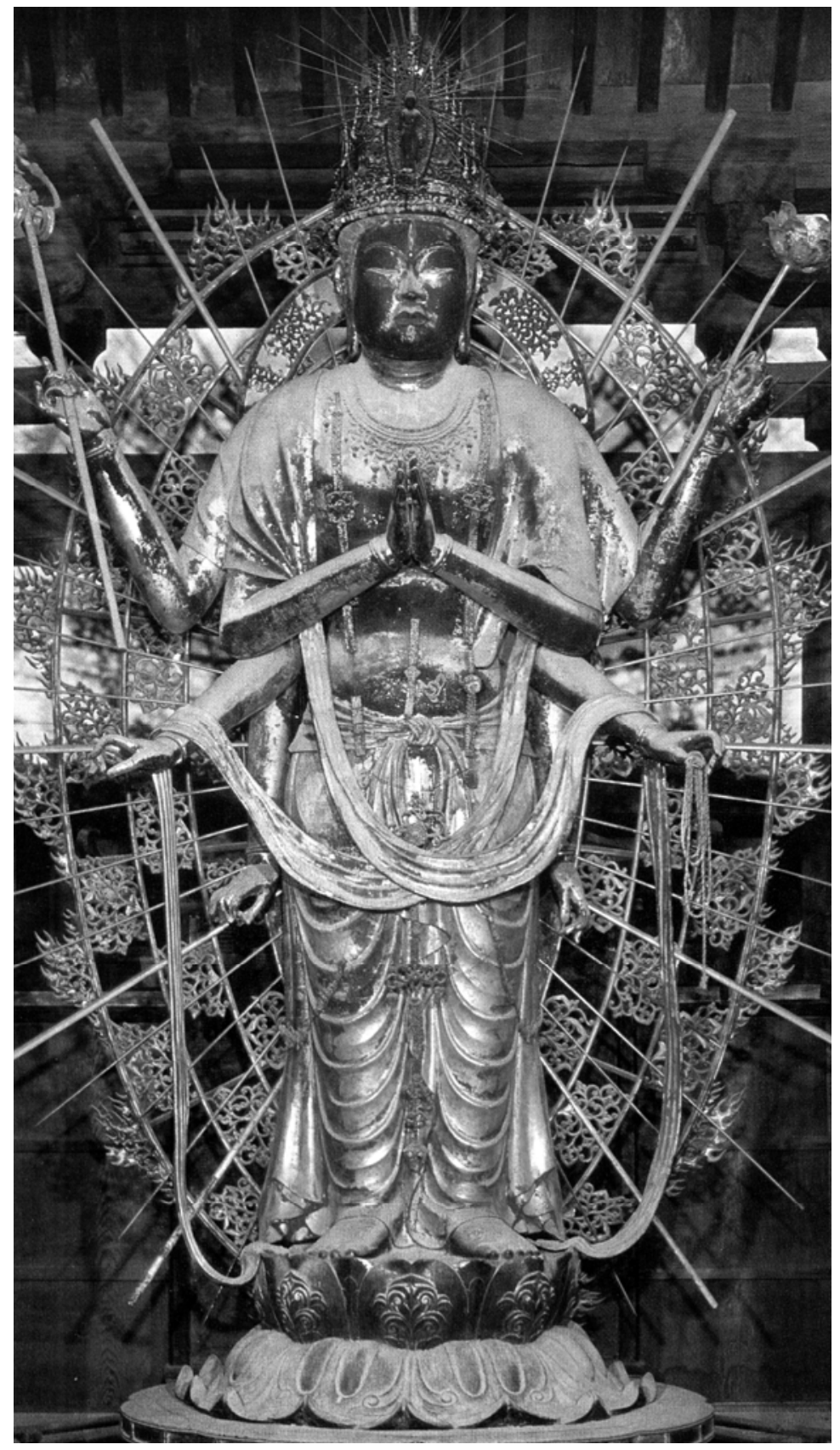

Culture and Cosmos 
164 Images of Stars and their Significance in Japanese Esoteric Art of the Heian Period

Fig. 2 Batō Kannon. Inanaki-dō, Daian-ji, Nara.

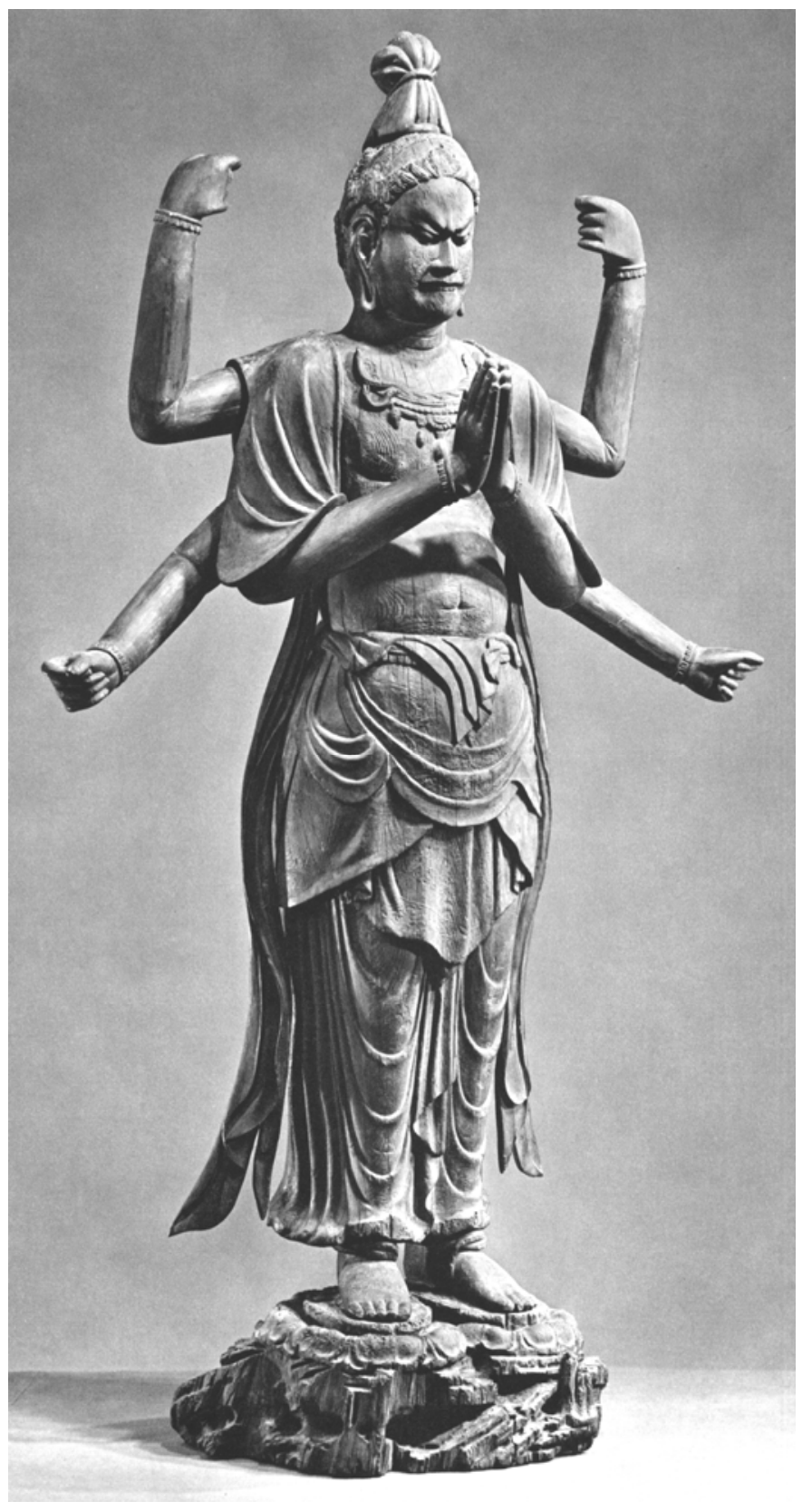

Culture and Cosmos 
Tsuda Tetsuei 165

Fig. 3 The Womb (Taizō) Mandala. Tō-ji, Kyoto.

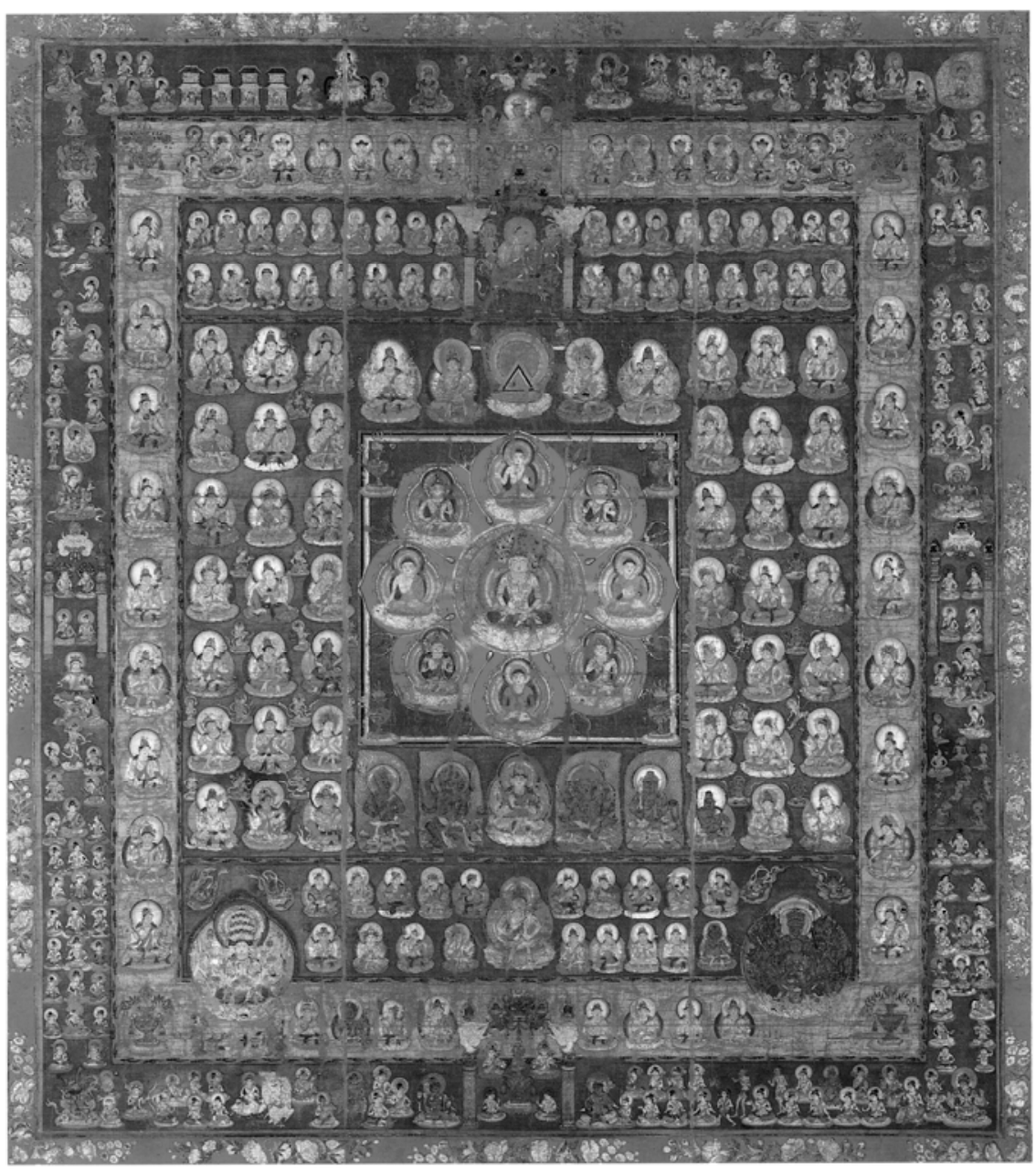

Culture and Cosmos 
166 Images of Stars and their Significance in Japanese Esoteric Art of the Heian Period

Fig. 4 Nyoirin Kannon. Kanshin-ji, Osaka.

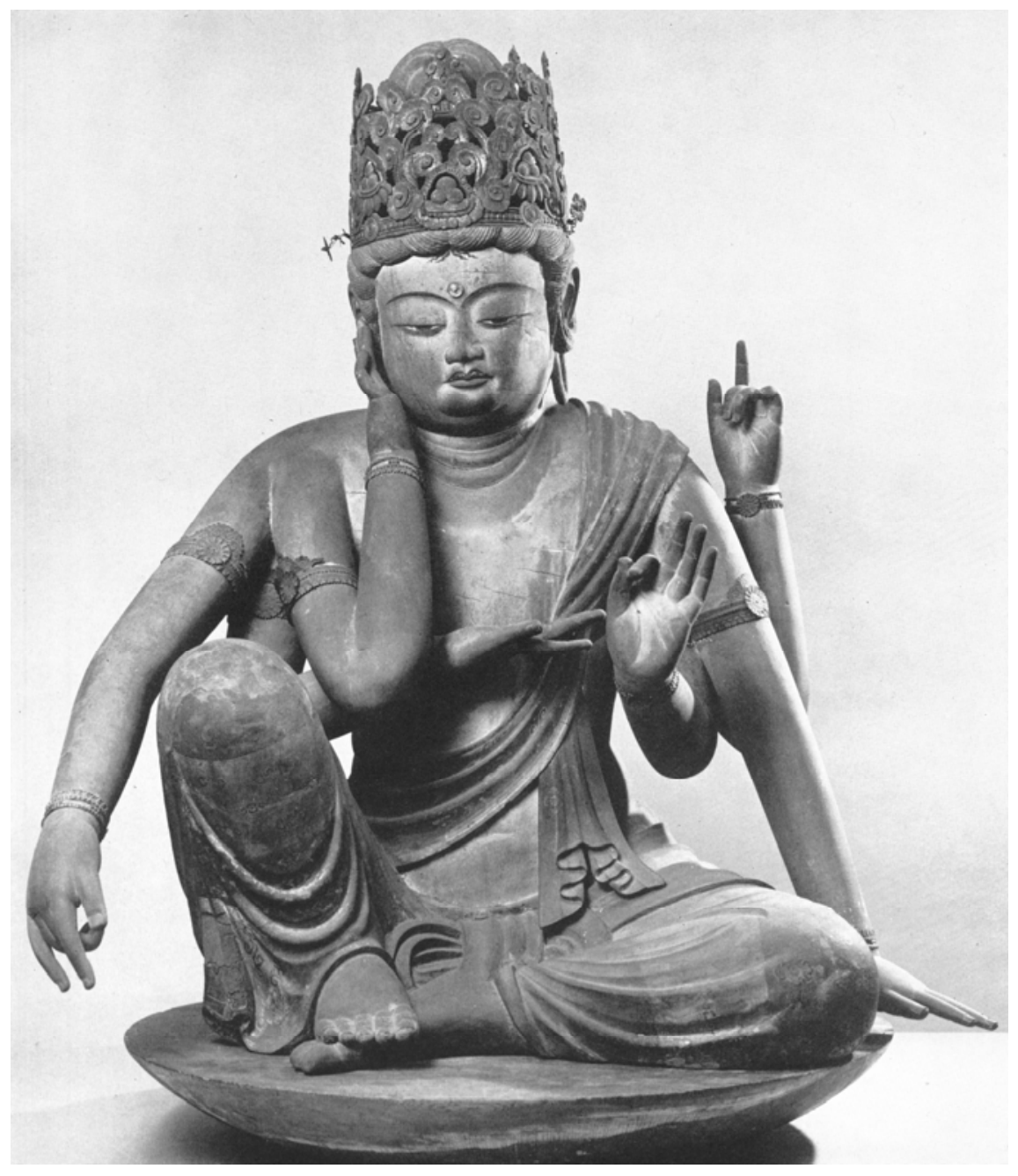

Culture and Cosmos 
Tsuda Tetsuei 167

Fig. 5 Nyoirin Kannon, from the Kannon-in section of the Womb Mandala. Jingo-ji, Kyoto.

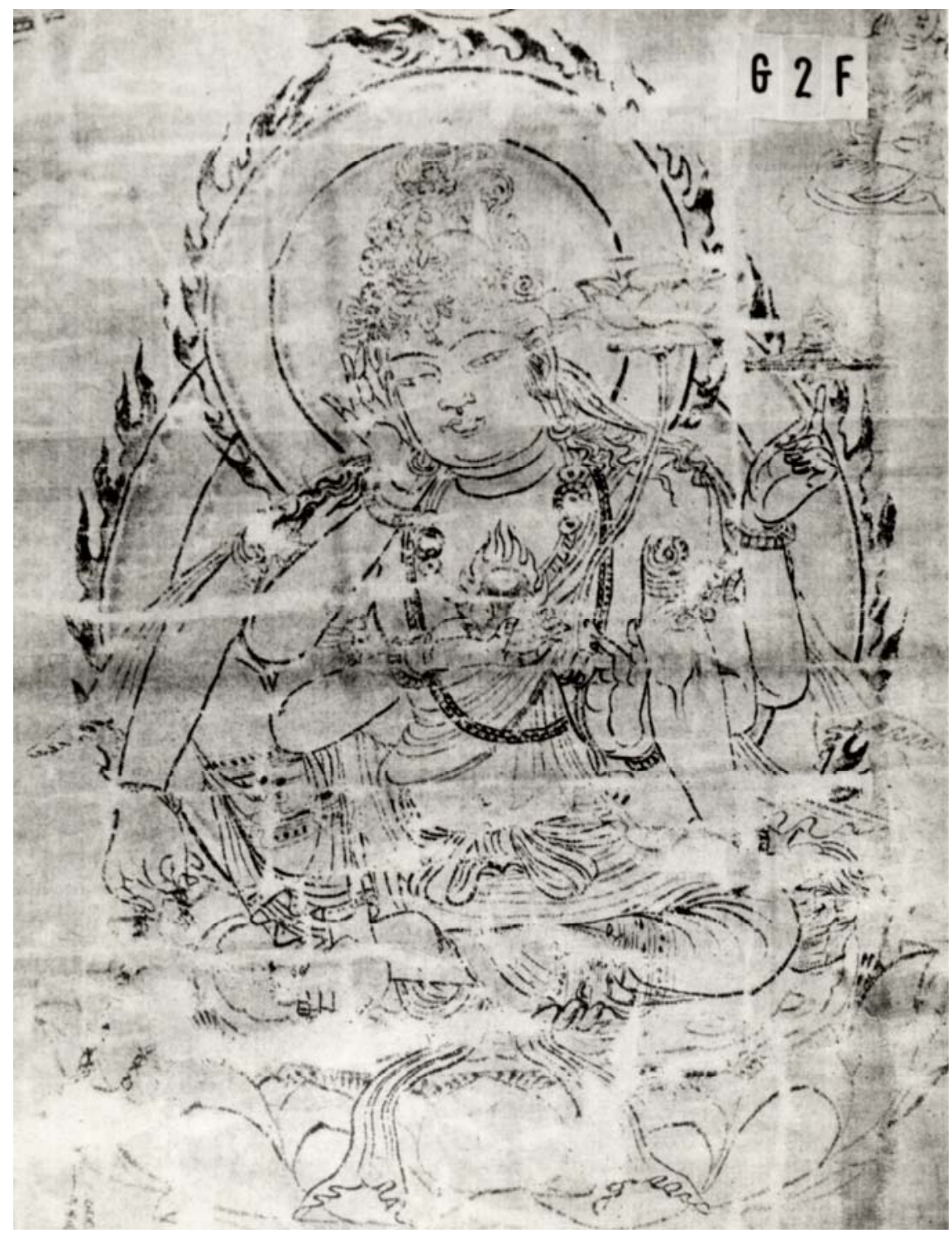


168 Images of Stars and their Significance in Japanese Esoteric Art of the Heian Period

Fig. 6 Nyoirin Kannon. Daigo-ji, Kyoto.

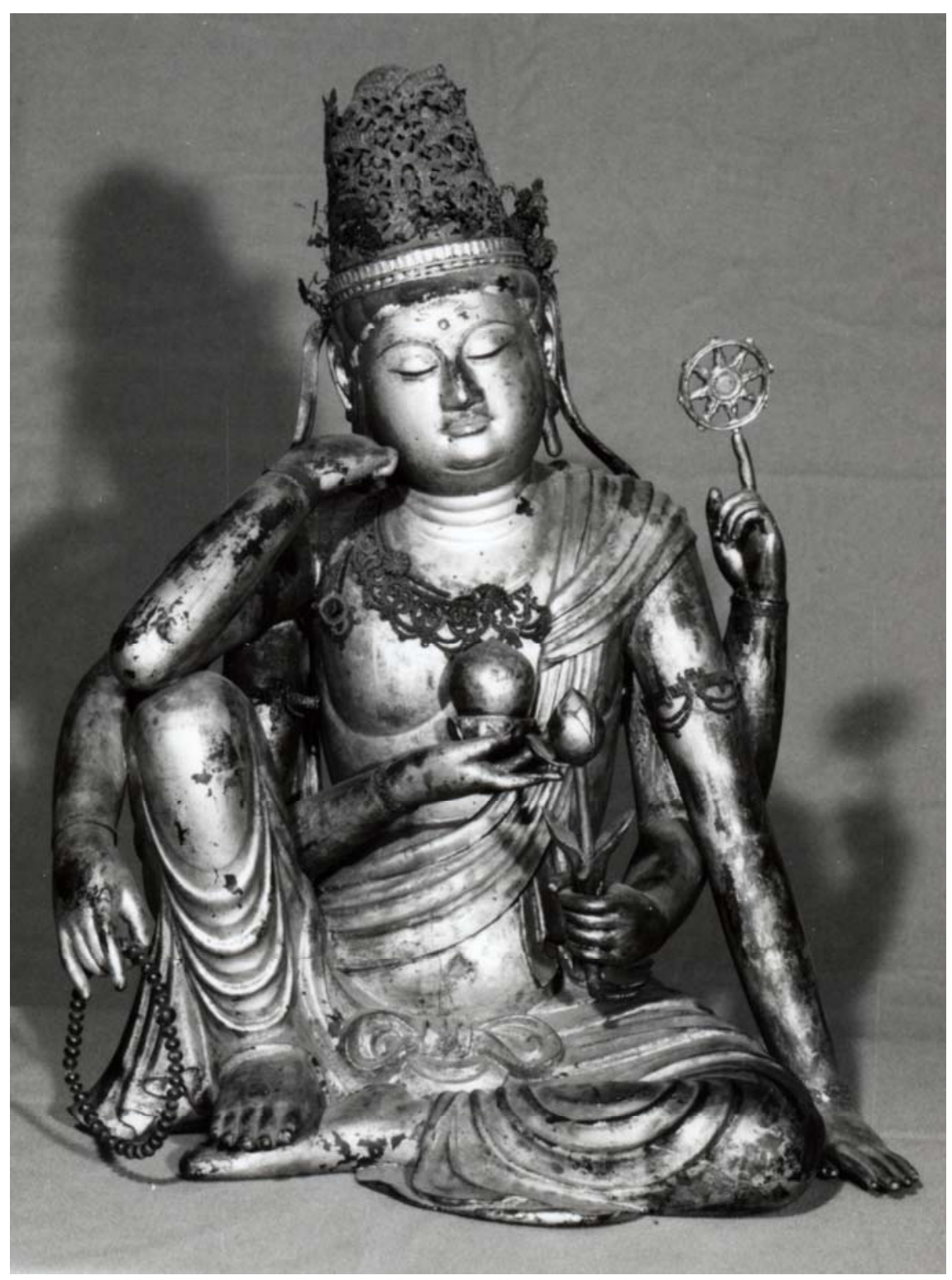

Culture and Cosmos 
Tsuda Tetsuei 169

Fig. 7 The meditation hand of the Nyoirin Kannon of Daigo-ji.

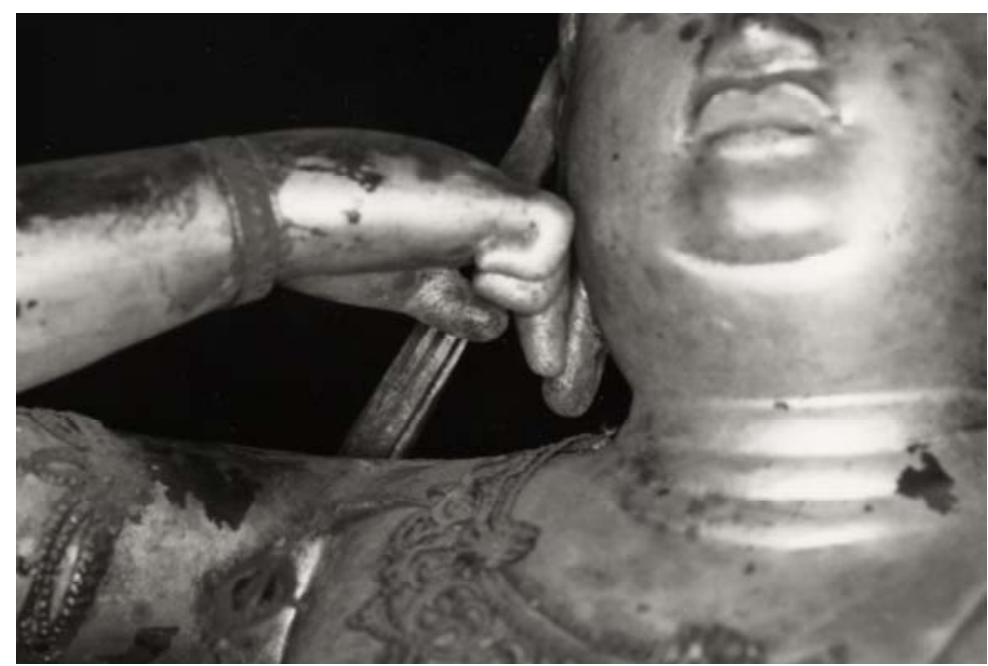

Culture and Cosmos 
170 Images of Stars and their Significance in Japanese Esoteric Art of the Heian Period

Fig. 8. 1 and 2 (This and following page) The two attendant bodhisattvas of the Amida triad. Seiryō-ji, Kyoto.

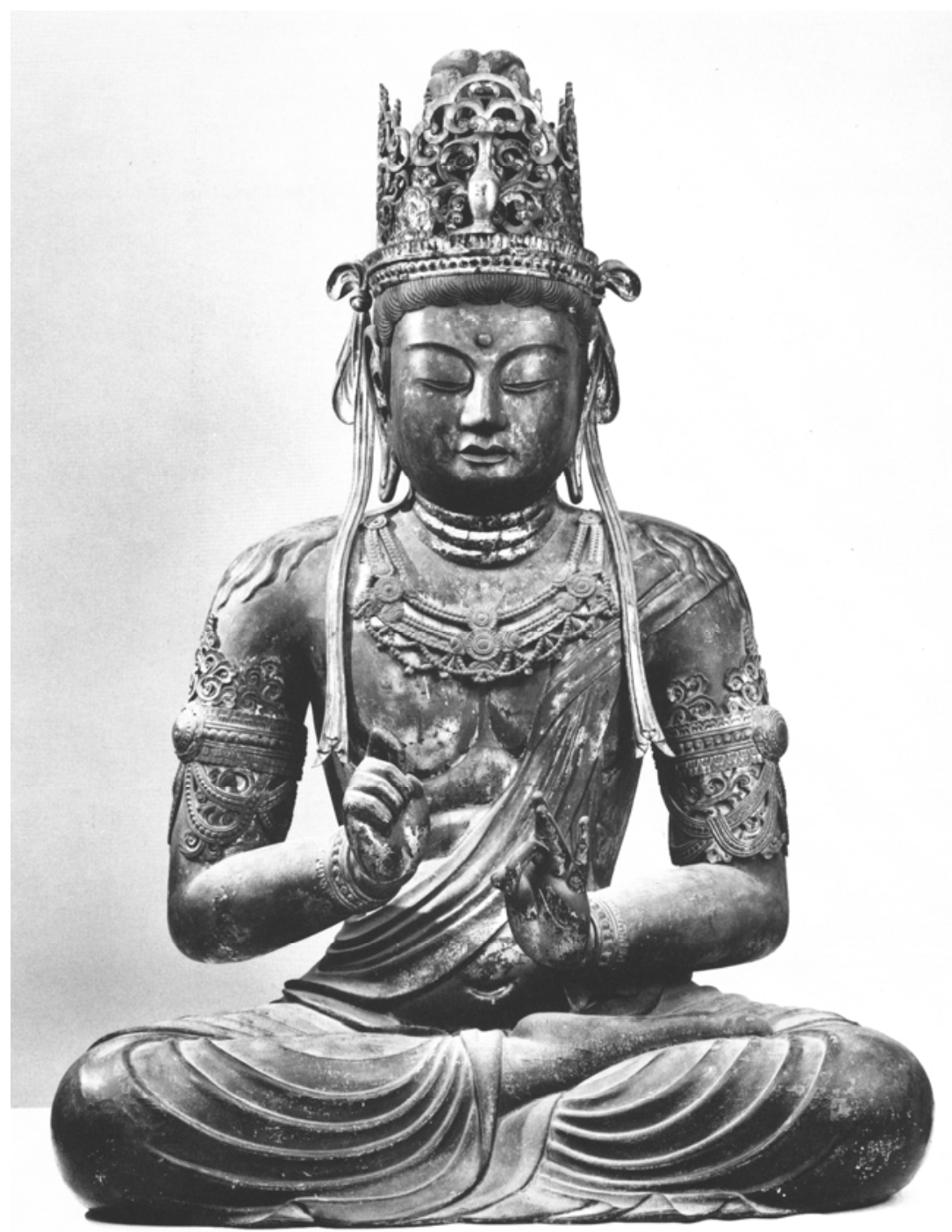

Culture and Cosmos 
Tsuda Tetsuei 171

Fig 8.2

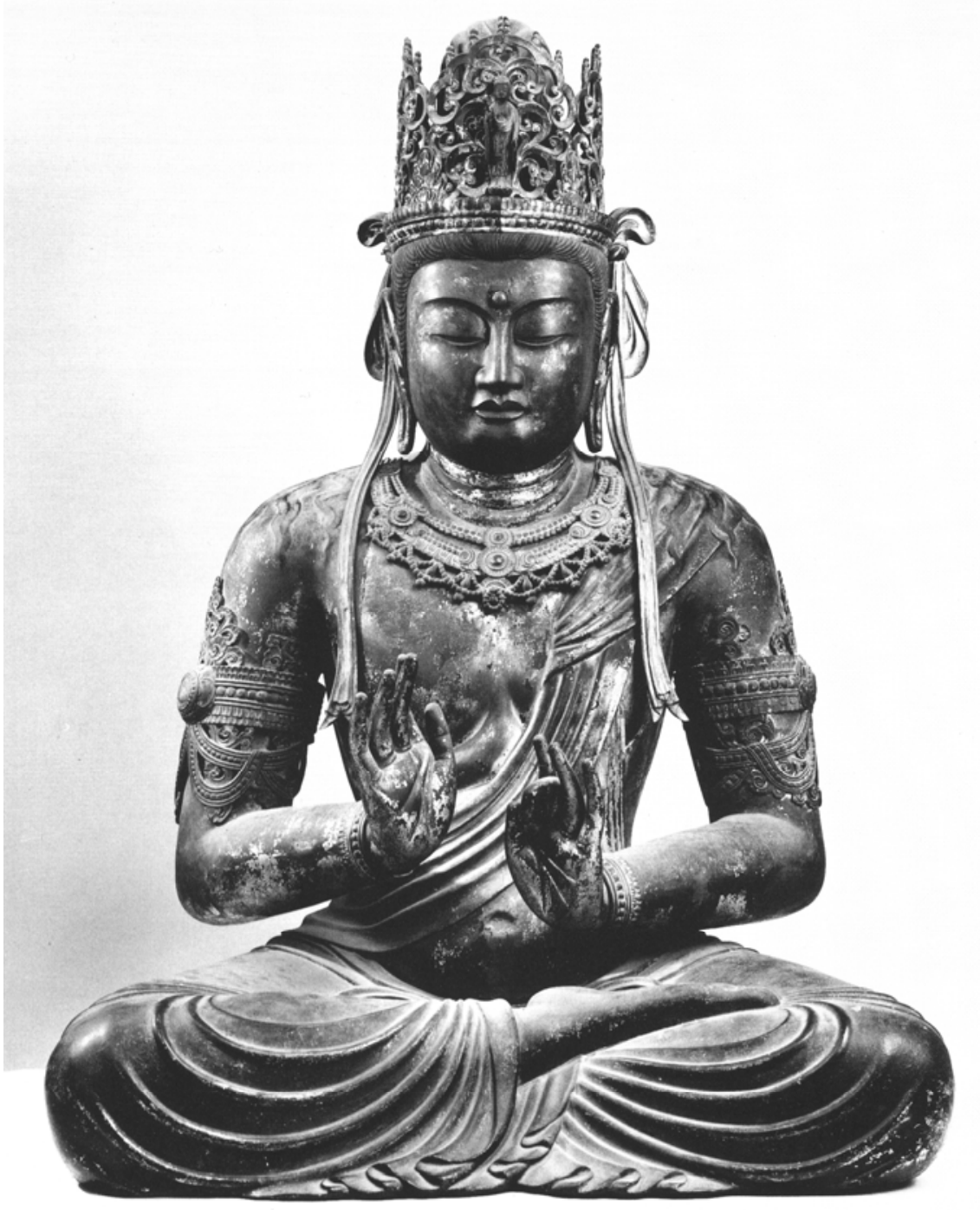

Culture and Cosmos 
172 Images of Stars and their Significance in Japanese Esoteric Art of the Heian Period

Fig. 9 The Buddha Dainichi and his mudrās. Ueno-an-ji, Shiga Prefecture.
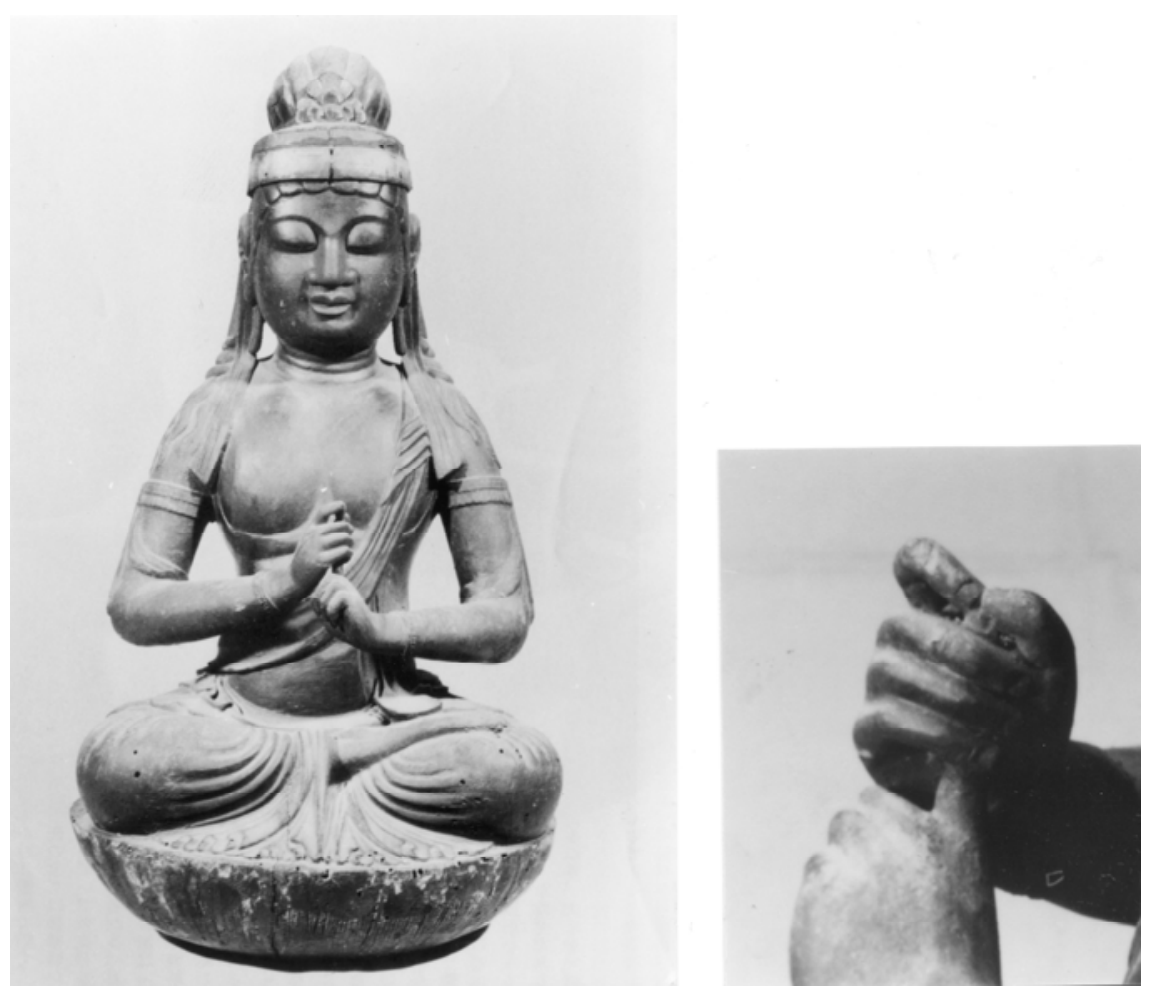

Culture and Cosmos 
Tsuda Tetsuei 173

Culture and Cosmos 
174 Images of Stars and their Significance in Japanese Esoteric Art of the Heian Period

Fig. 10 Shijōkō (Blazing Light) Mandala from the Asabashō. Eizan-bunko Library, Shiga Prefecture.

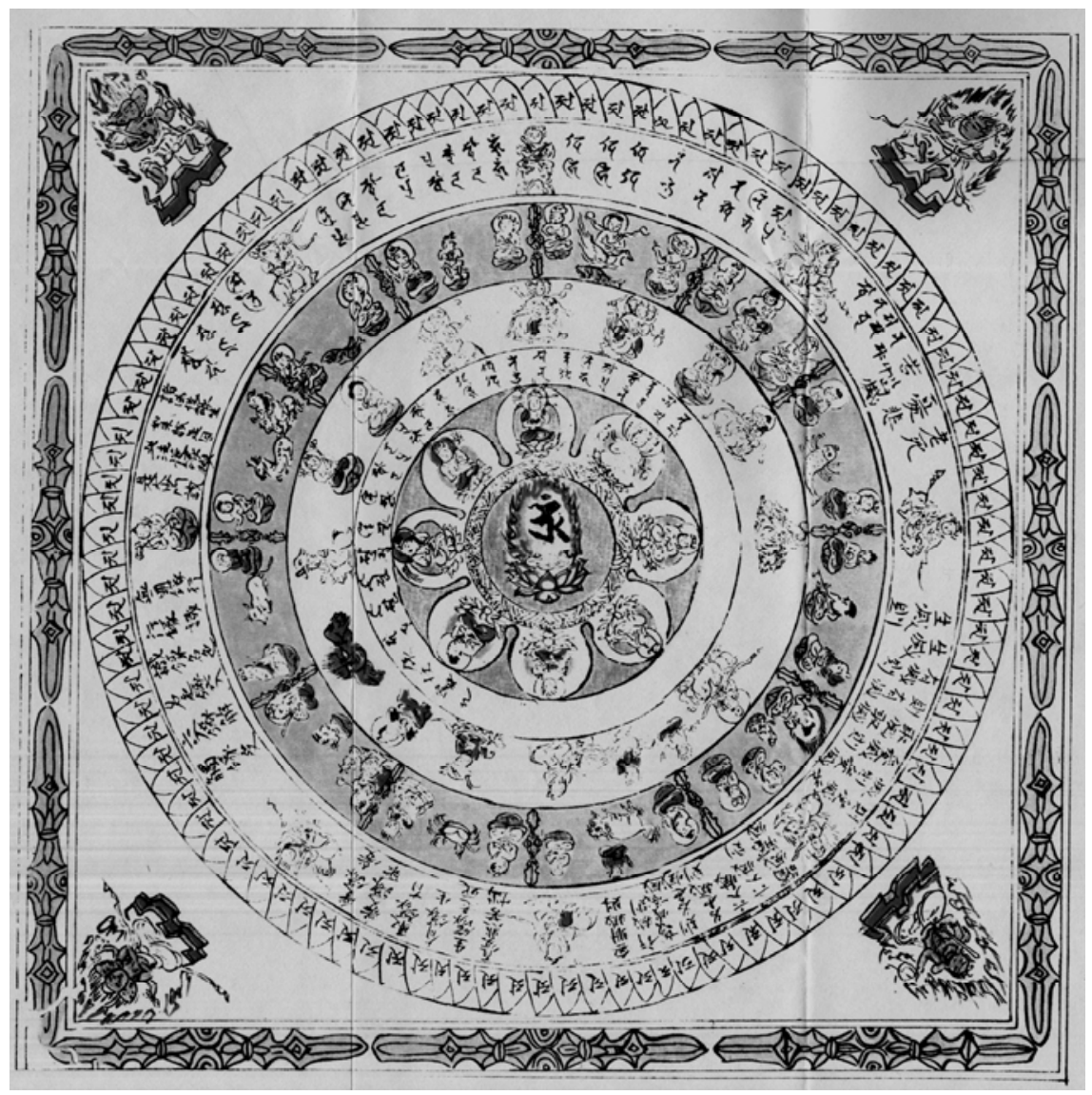

Culture and Cosmos 
Fig. 11 Nyoirin Kannon and the seven stars of the Big Dipper. Gumȳ̄-ji, Kanagawa Prefecture. The eighth deity included in this representation is Kishimojin (Sk: Hārītī).

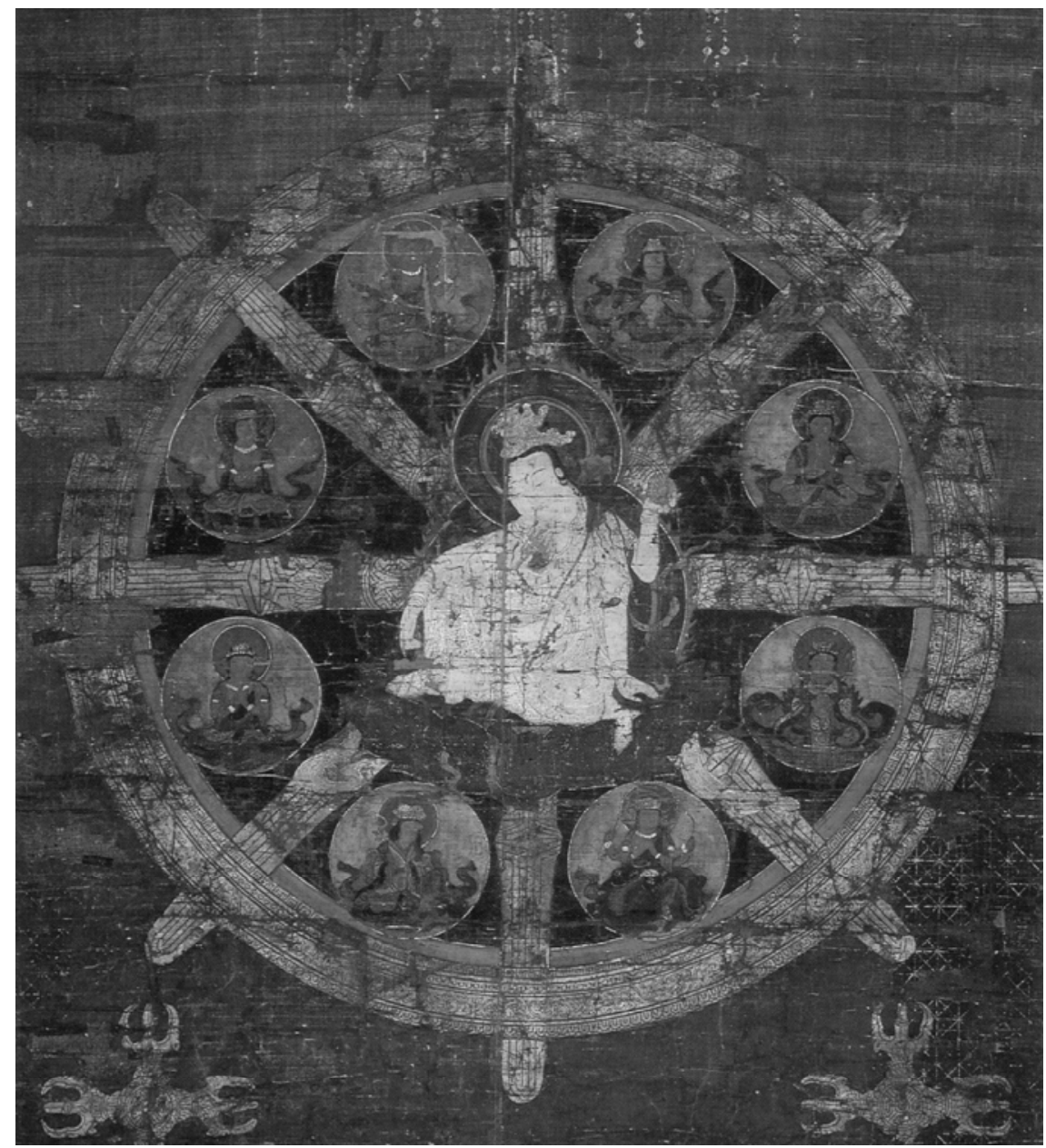


176 Images of Stars and their Significance in Japanese Esoteric Art of the Heian Period

Fig. 12 Detail of the Shūnanzan Mandala. Matsuo-ji, Kyoto.

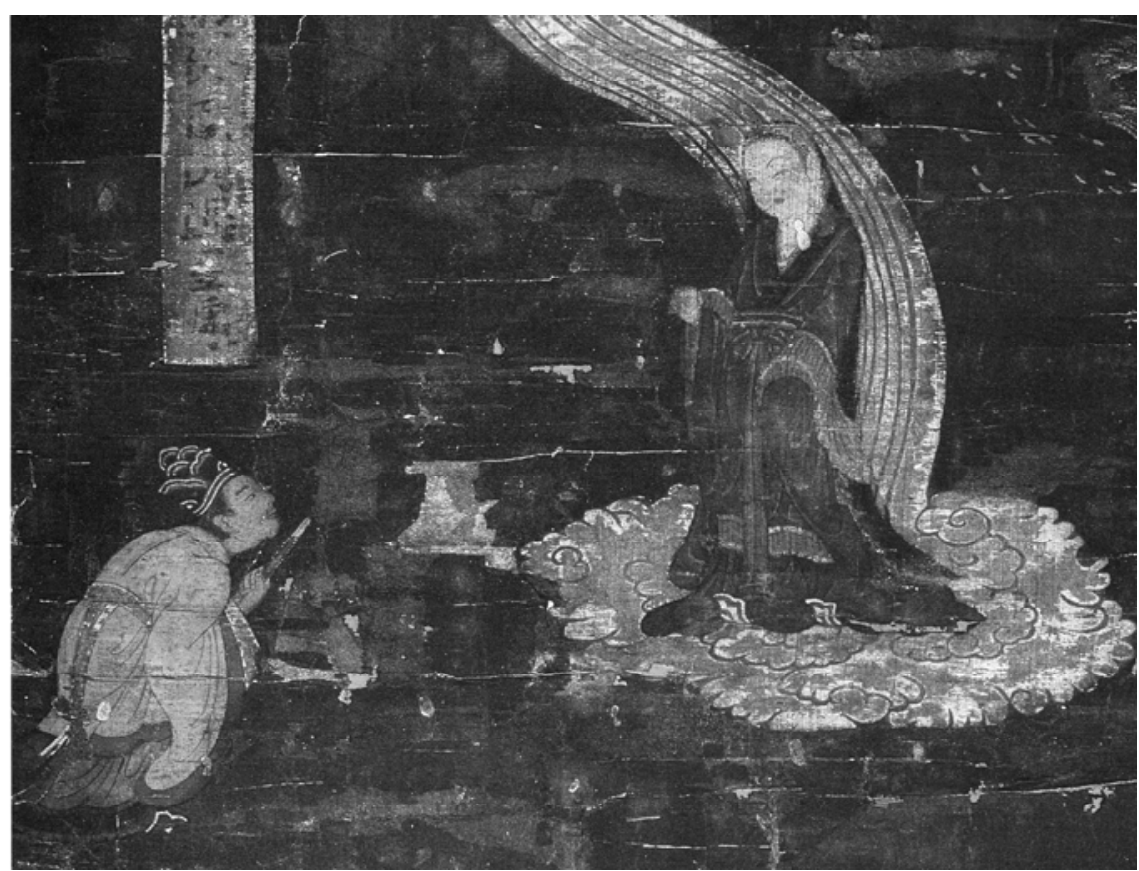

Culture and Cosmos 
Fig.13 Karazu. Tō-ji, Kyoto.

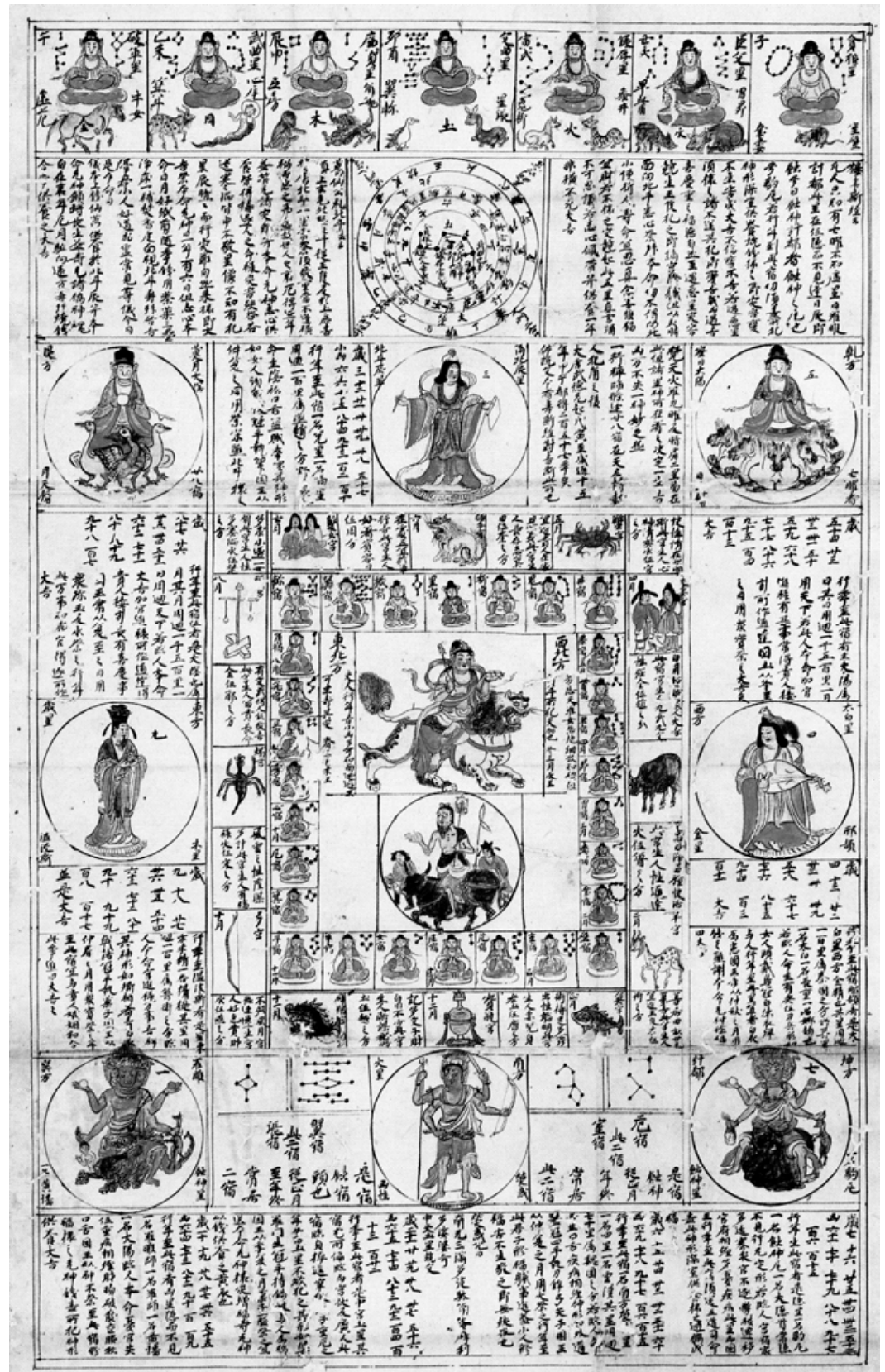

Culture and Cosmos 
178 Images of Stars and their Significance in Japanese Esoteric Art of the Heian Period

Fig.14 The rectangular star mandala created by Kankū. From Shike zuzōshō,. To-ji, Daigo-ji.

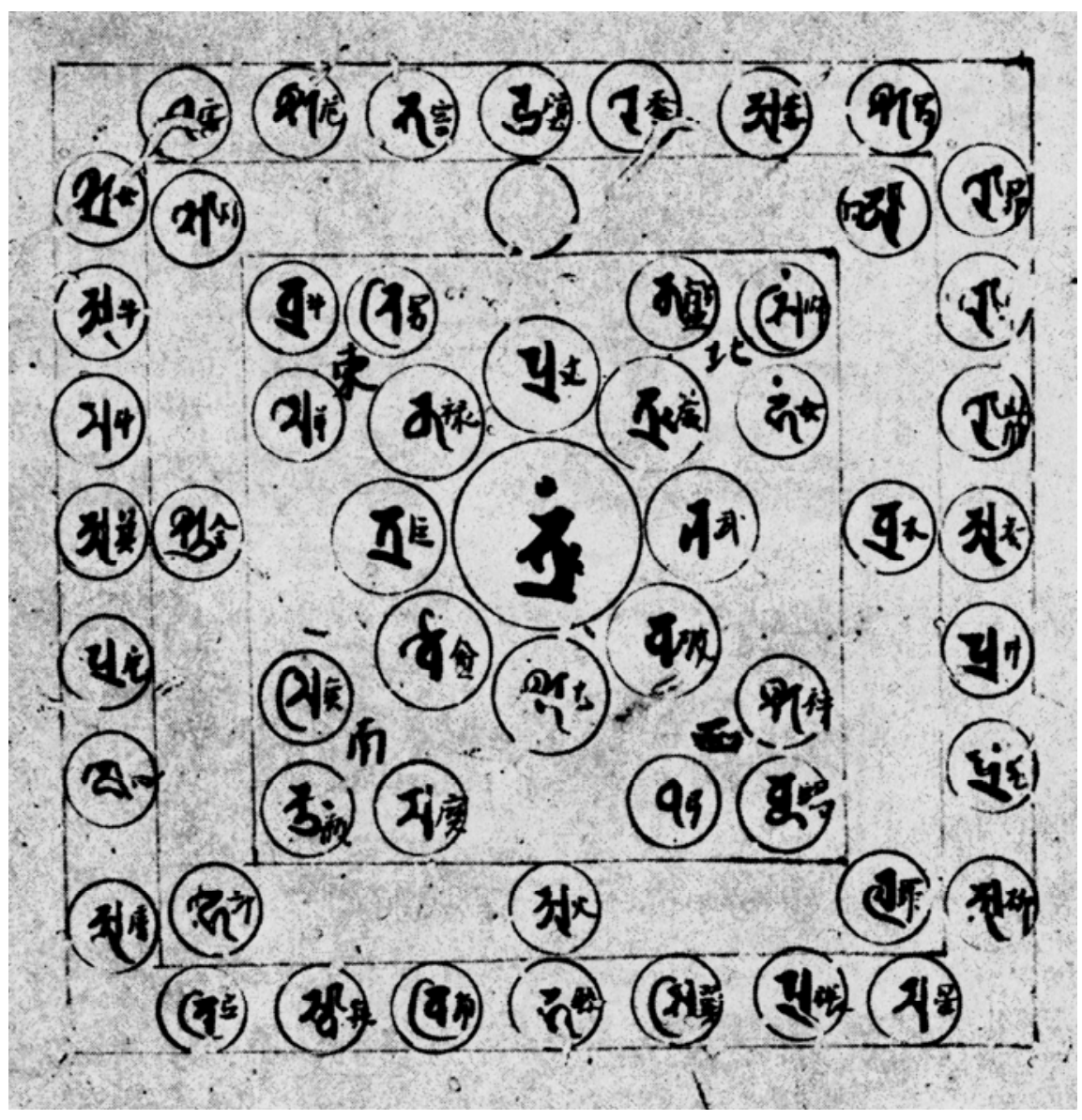


Tsuda Tetsuei 179

Fig.15 The Blazing Light Buddha and the Nine Luminaries. Hermitage Museum, St. Petersburg.

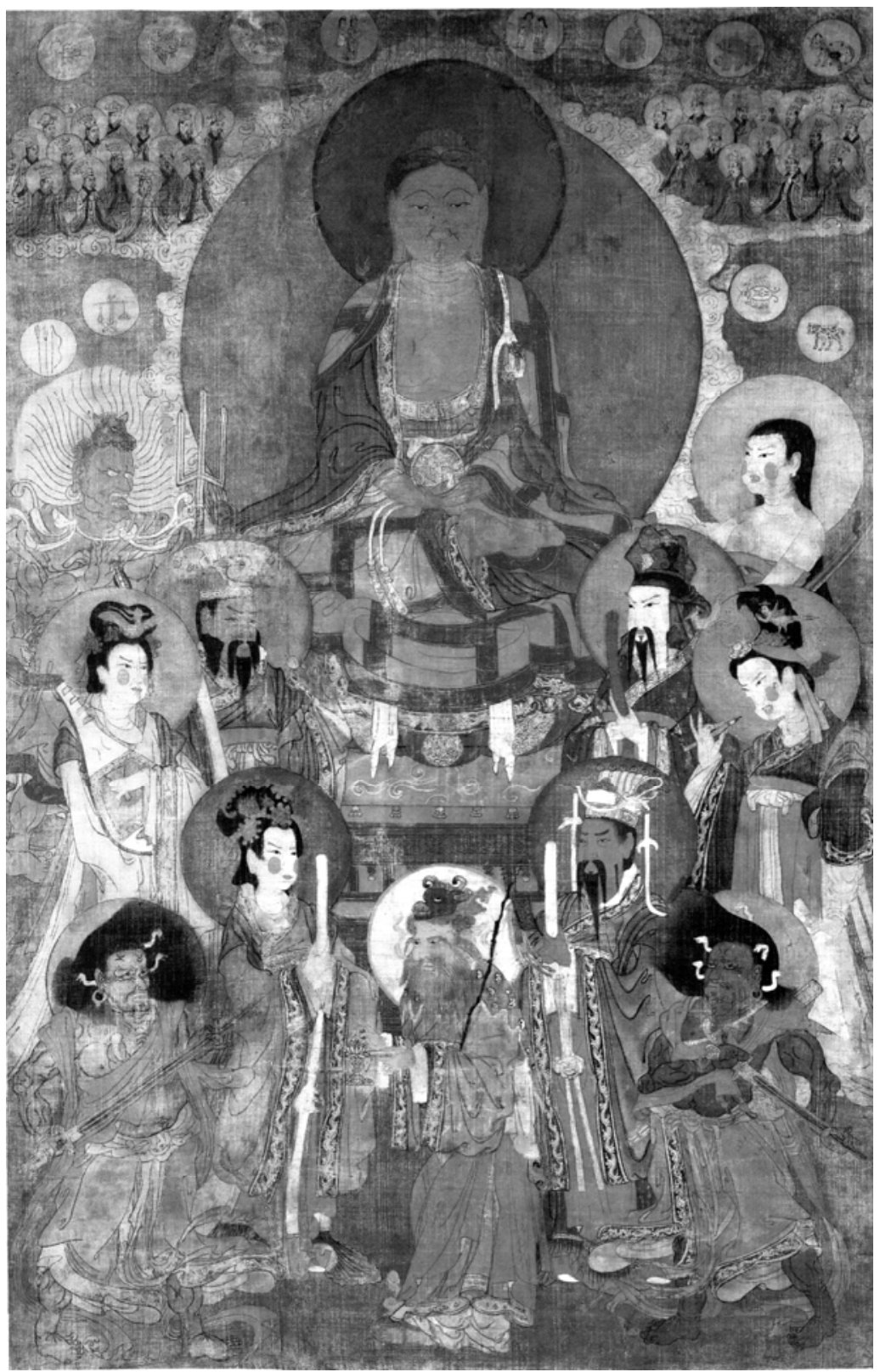

Culture and Cosmos 
180 Images of Stars and their Significance in Japanese Esoteric Art of the Heian Period

Fig. 16 Central eight-petalled lotus section of the Womb World Mandala. Tō-ji, Kyoto.

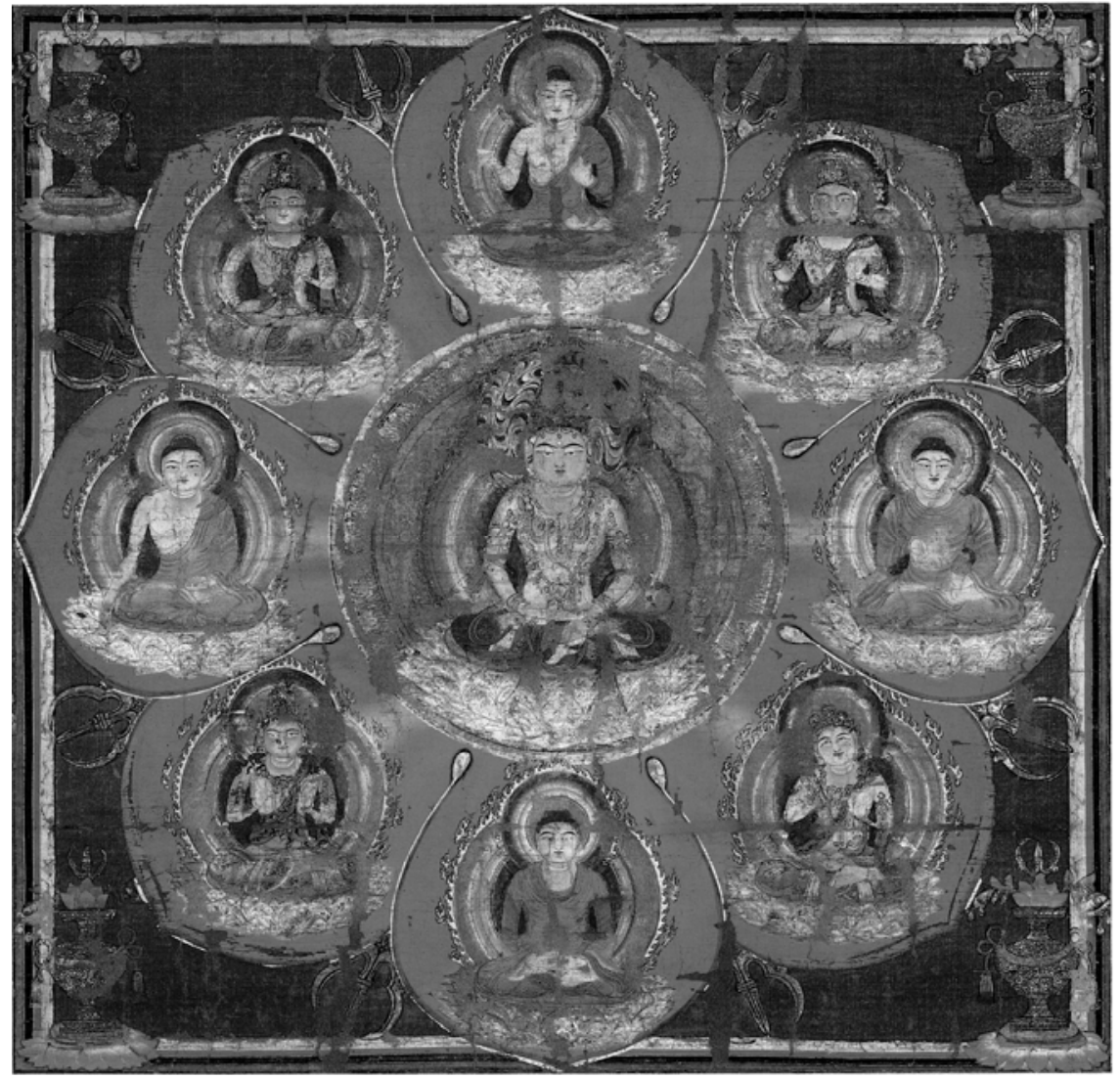

Culture and Cosmos 
Tsuda Tetsuei 181

Fig. 17 Sonjōō Mandala from Besson zakki. Ninna-ji, Kyoto.

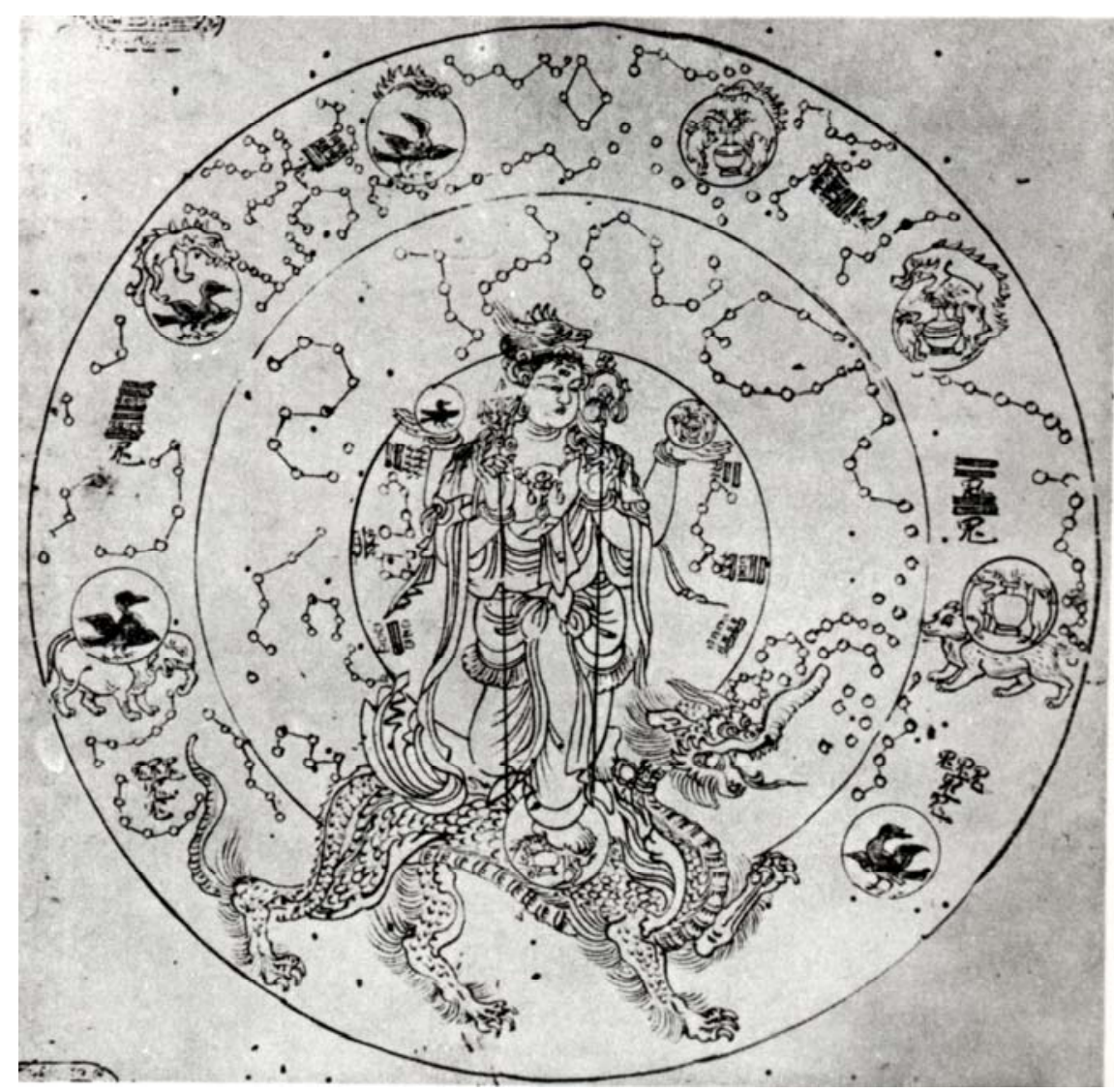

Culture and Cosmos 
182 Images of Stars and their Significance in Japanese Esoteric Art of the Heian Period

Fig. 18 Diagram of the night sky in the northern hemisphere. Tandai-ji, Fukui Prefecture.

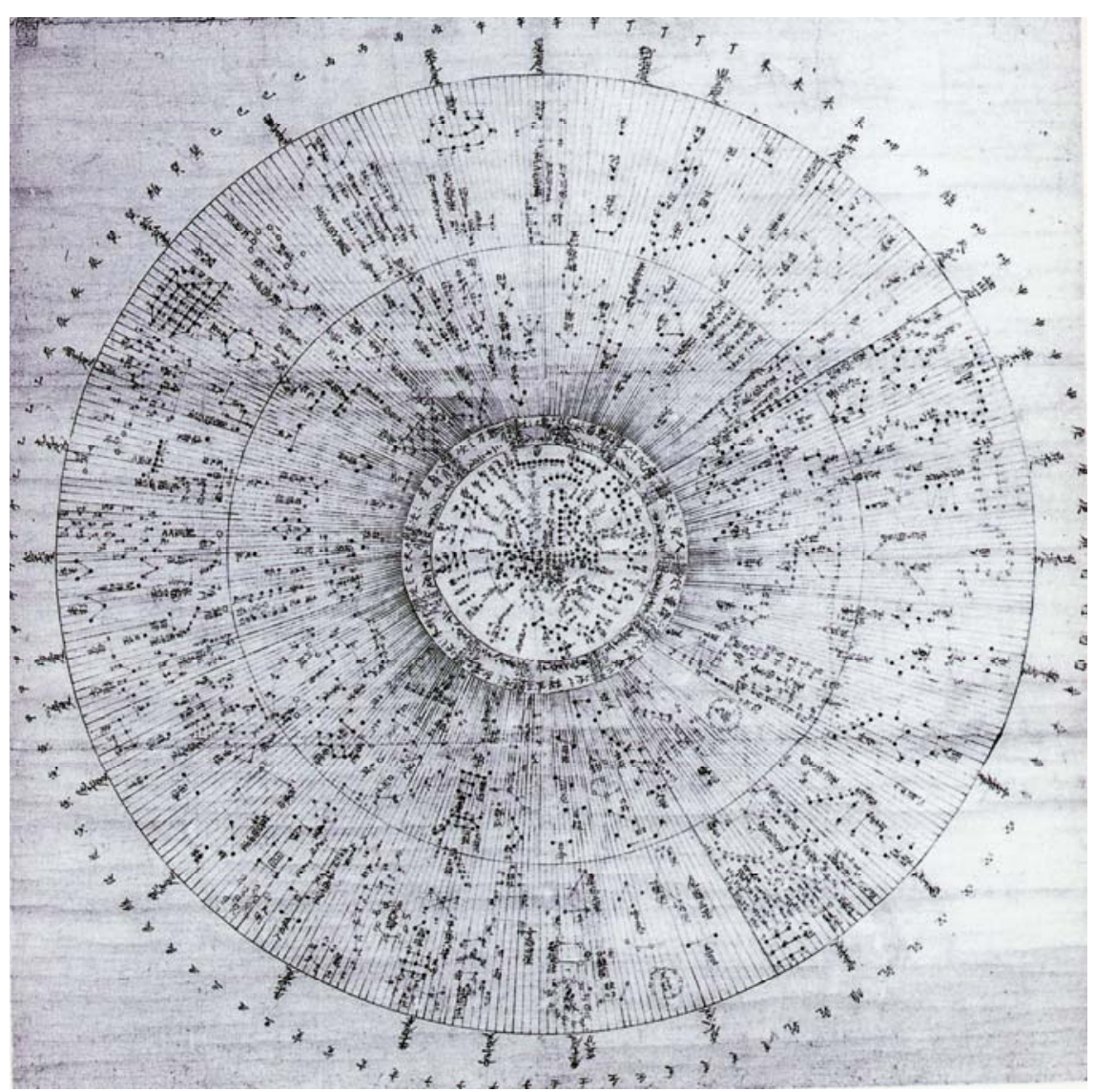

Culture and Cosmos 
Tsuda Tetsuei 183

Fig. 19 Detail of the Sonjōō Mandala from Besson zakki . Ninna-ji, Kyoto.

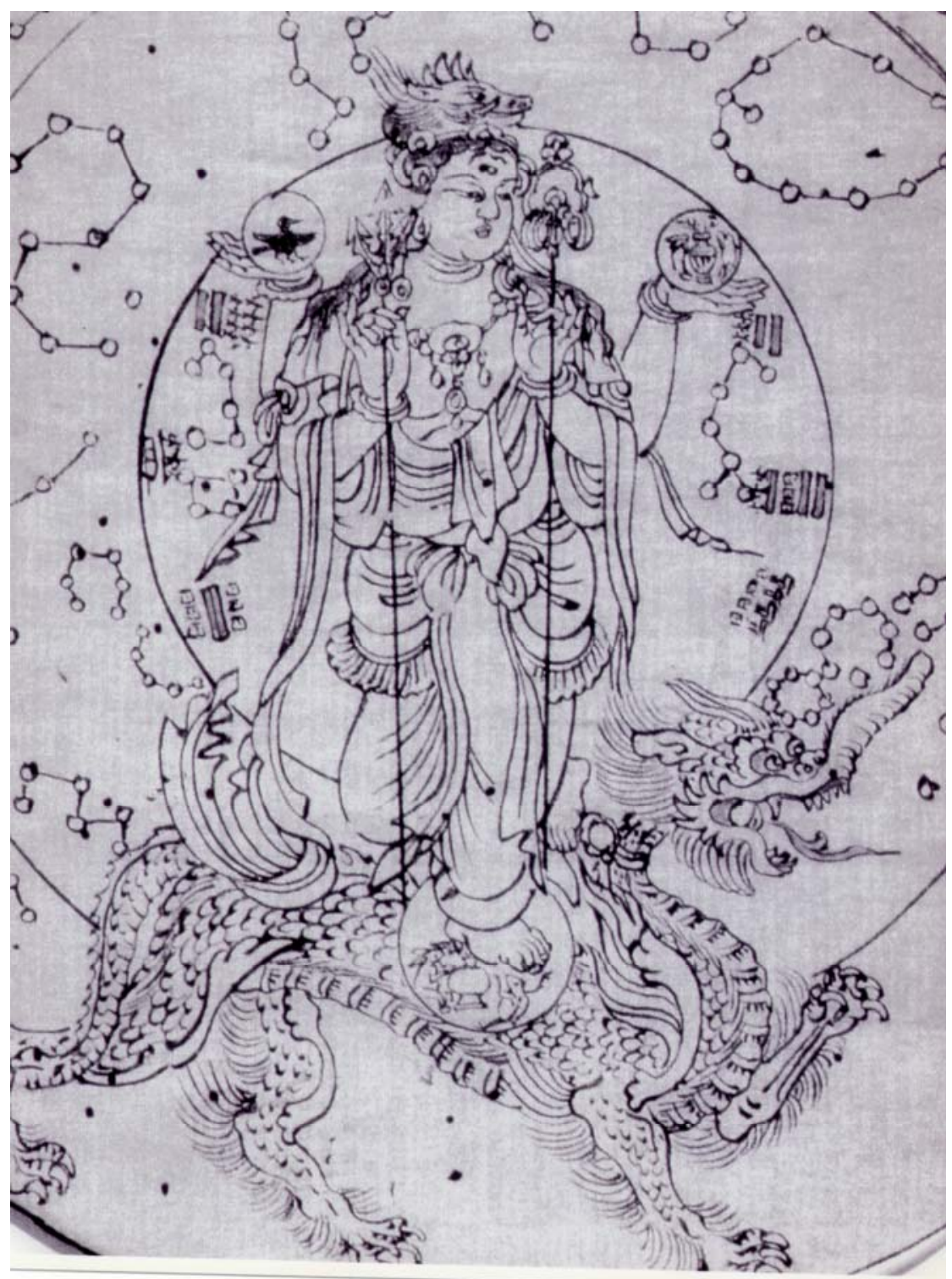

Culture and Cosmos 
184 Images of Stars and their Significance in Japanese Esoteric Art of the Heian Period

Fig. 20 Detail of the Butsugen Mandala showing Mercury. Honsen-ji, Tokyo.

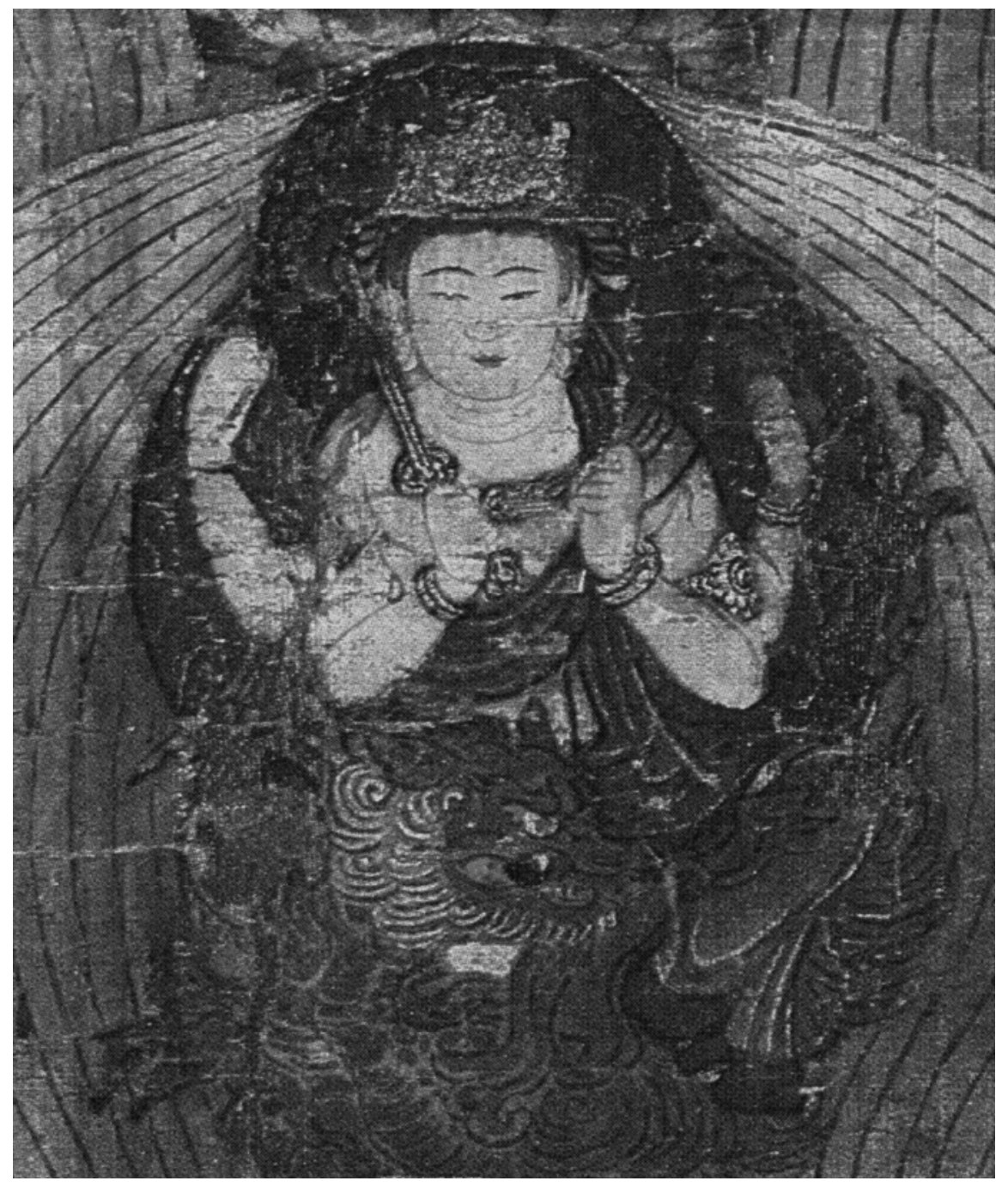

Culture and Cosmos 
Tsuda Tetsuei 185

Fig. 21 Guanyin (J: Kannon). Museum of Fine Arts, Boston.

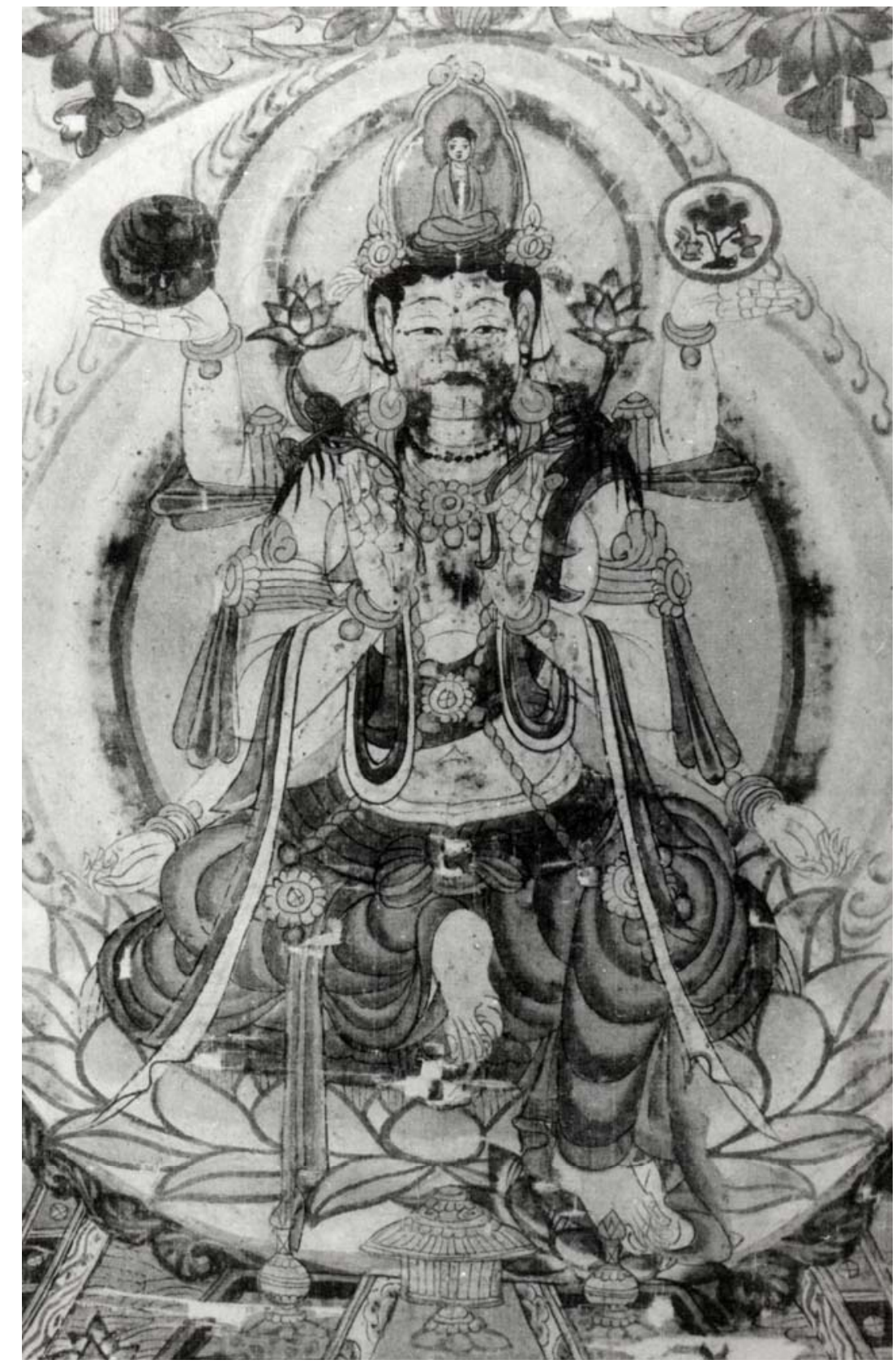

Culture and Cosmos 
186 Images of Stars and their Significance in Japanese Esoteric Art of the Heian Period

Fig. 22 Myōken Mandala from the Shoson zuzō. MOA Museum, Shizuoka Prefecture.

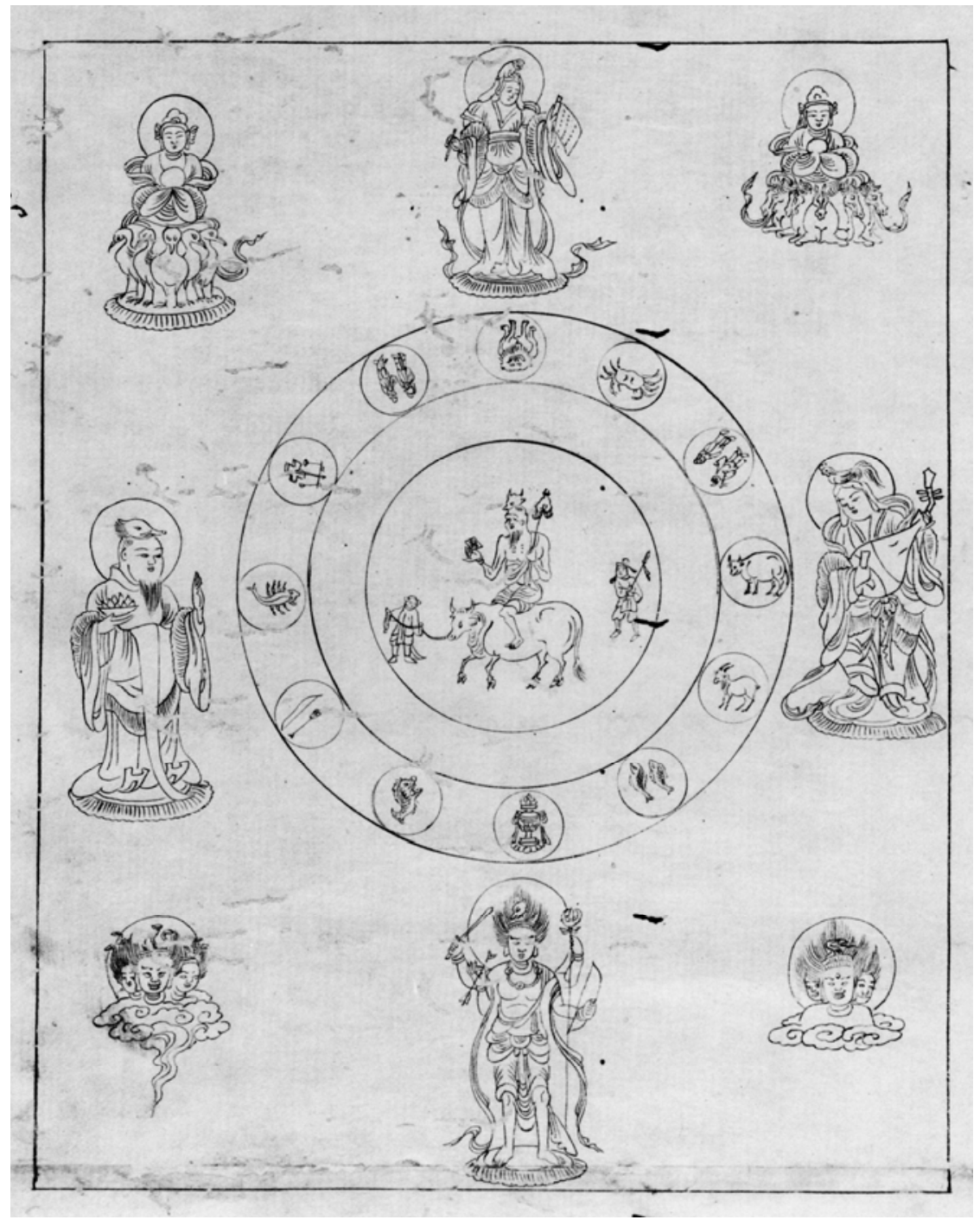

Culture and Cosmos 
Tsuda Tetsuei 187

Fig. 23 Saturn. Detail from the Bonten karazu. Tokyo National Museum.

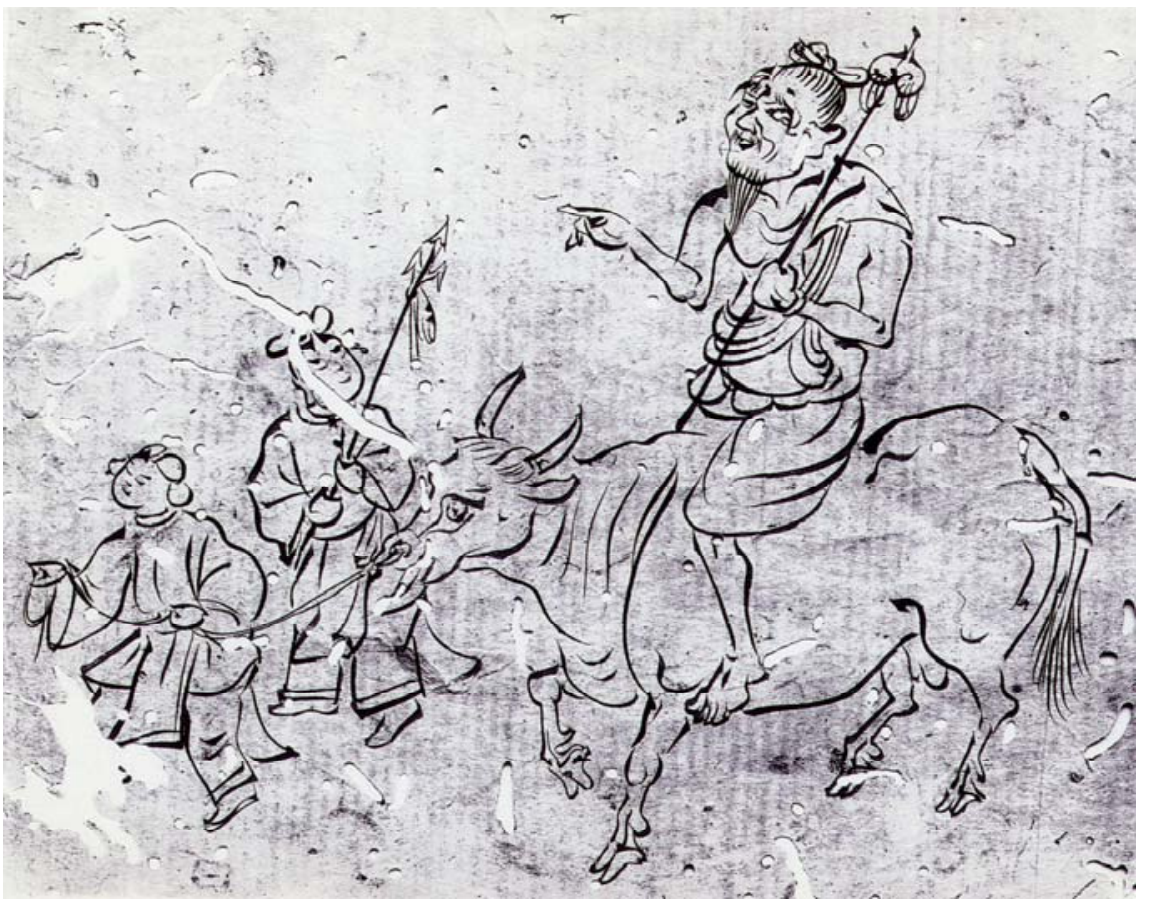


188 Images of Stars and their Significance in Japanese Esoteric Art of the Heian Period

Fig. 24 Circular star mandala. Hōryū-ji, Nara.

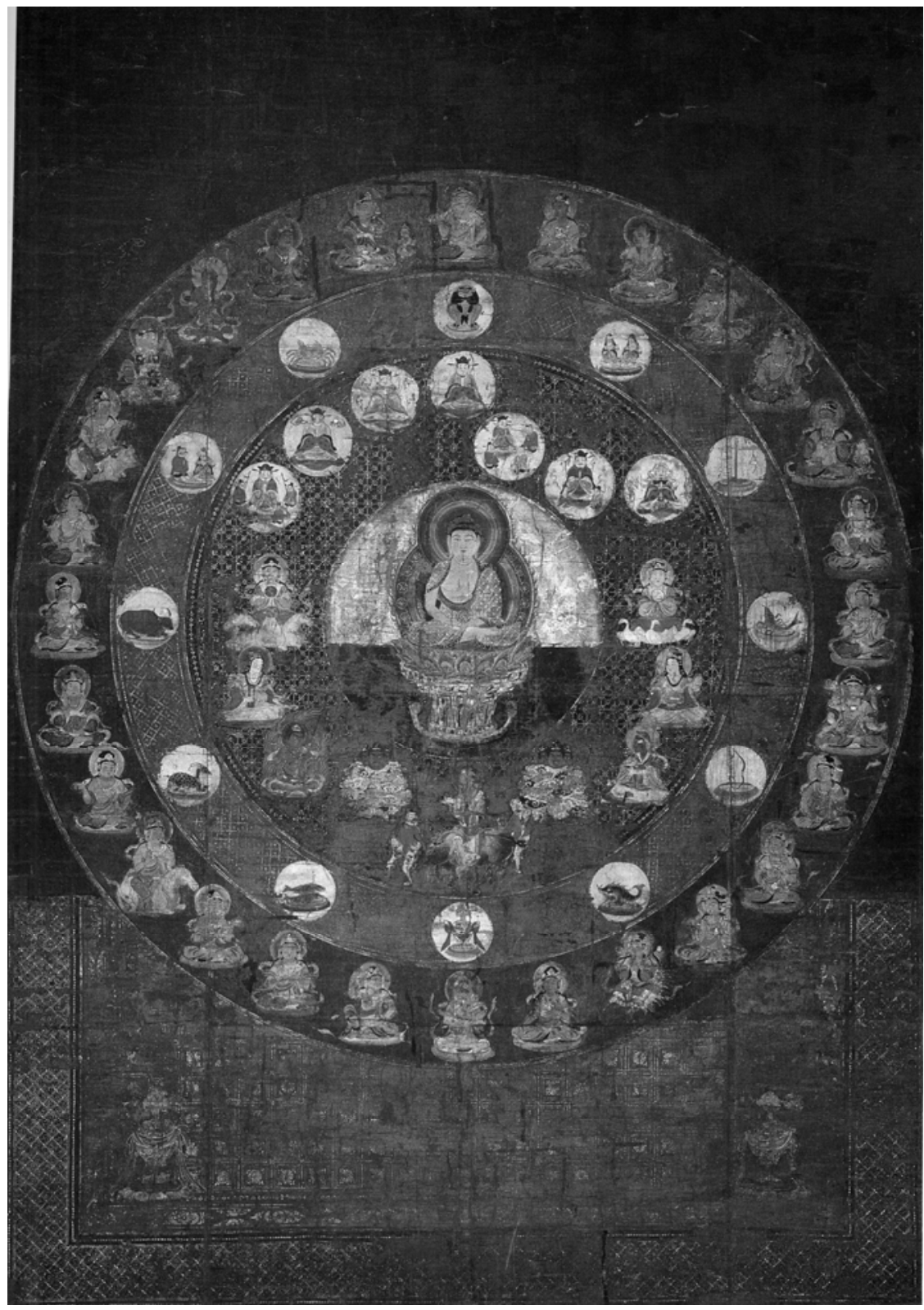

Culture and Cosmos 
Tsuda Tetsuei 189

Fig. 25 Detail of the circular Star Mandala. Hōryū -ji, Nara.

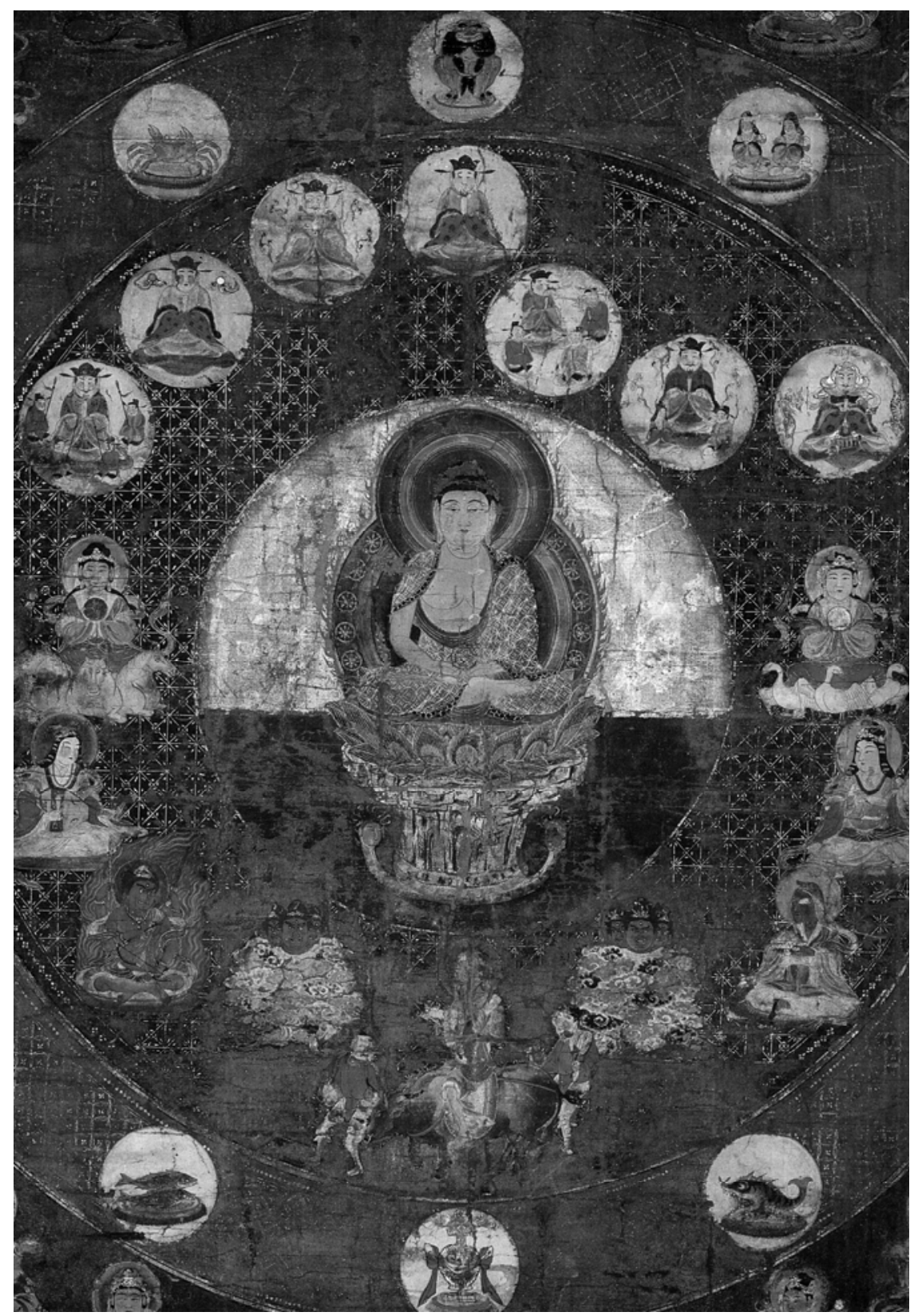

Culture and Cosmos 
190 Images of Stars and their Significance in Japanese Esoteric Art of the Heian Period

Fig. 26 Rectangular star mandala. Kumeta-ji, Osaka.

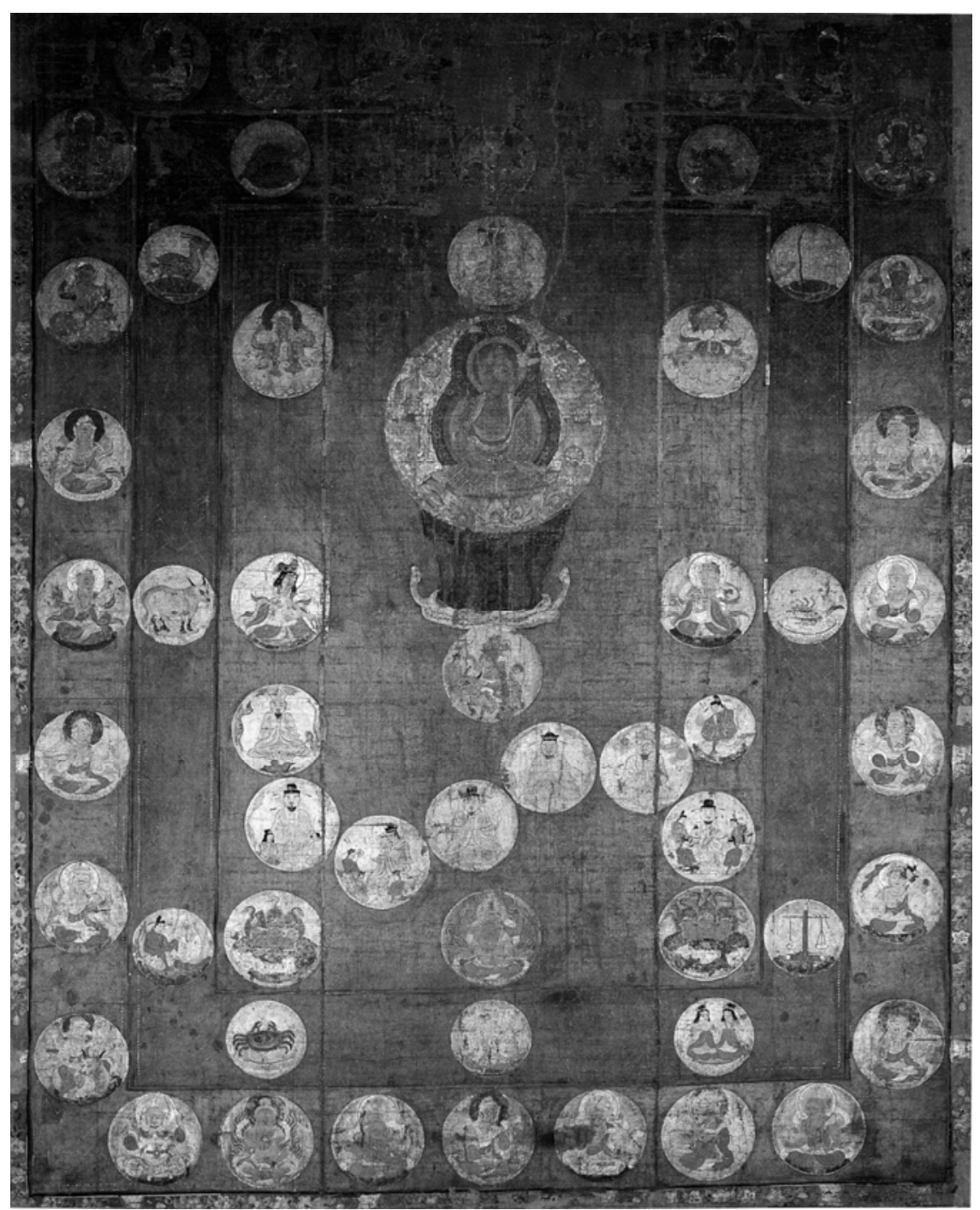

Culture and Cosmos 
Tsuda Tetsuei 191

Fig. 27 Detail of the rectangular star mandala. Kumeta-ji, Osaka.

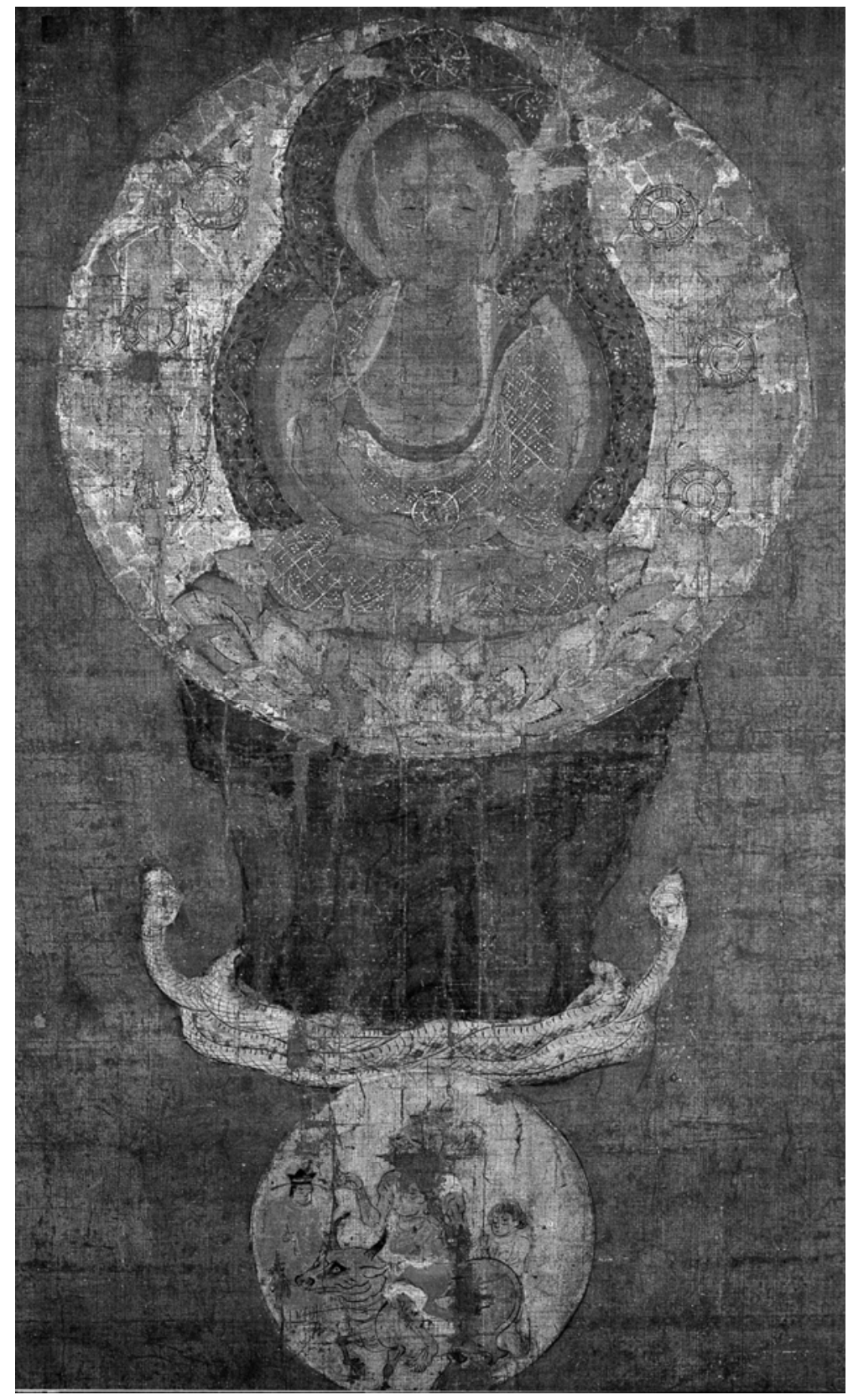

Culture and Cosmos 
192 Images of Stars and their Significance in Japanese Esoteric Art of the Heian Period

Fig. 28 The Seven Star Seven Yakushi Buddhas. Tōkō-in, Chiba Prefecture.

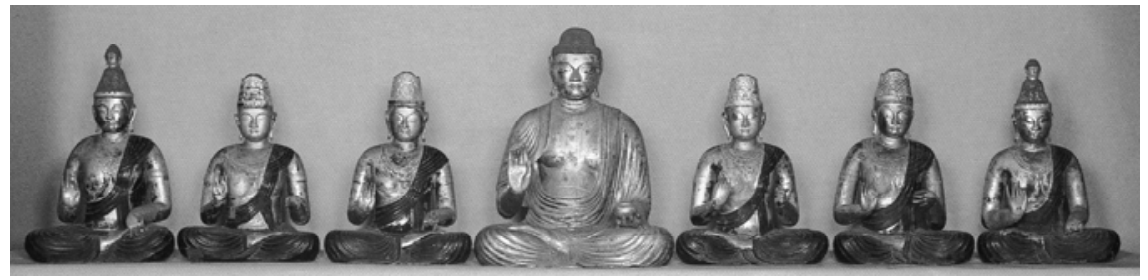

Fig. 29 Guardian deity. Tōkō -in, Chiba Prefecture.

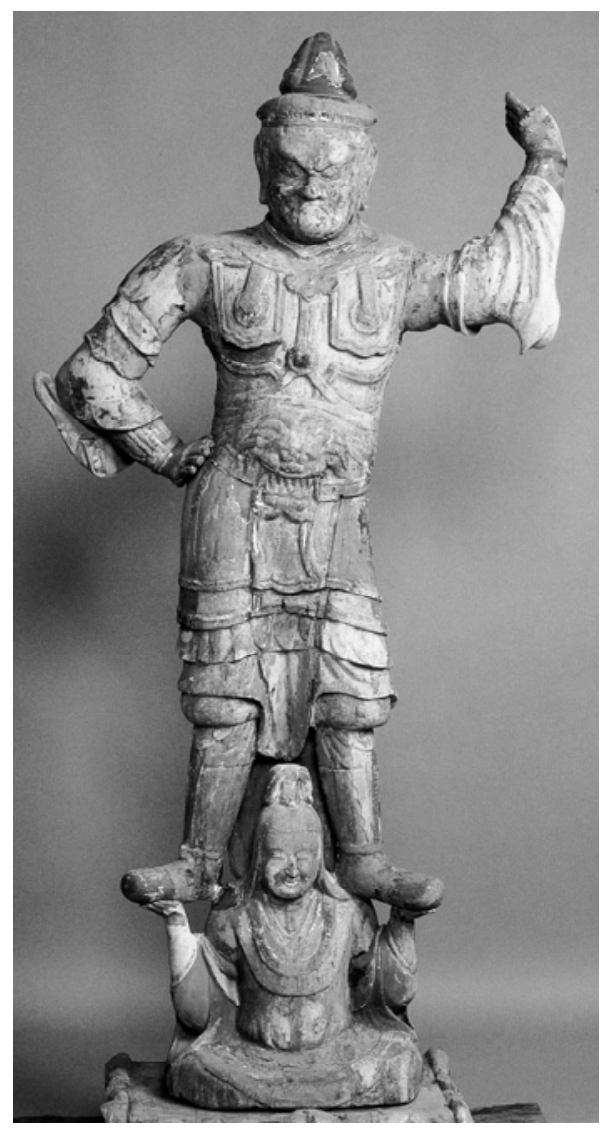

Culture and Cosmos 
Fig. 30 Rokujikyō Mandala from Besson-zakki. Ninna-ji, Kyoto.

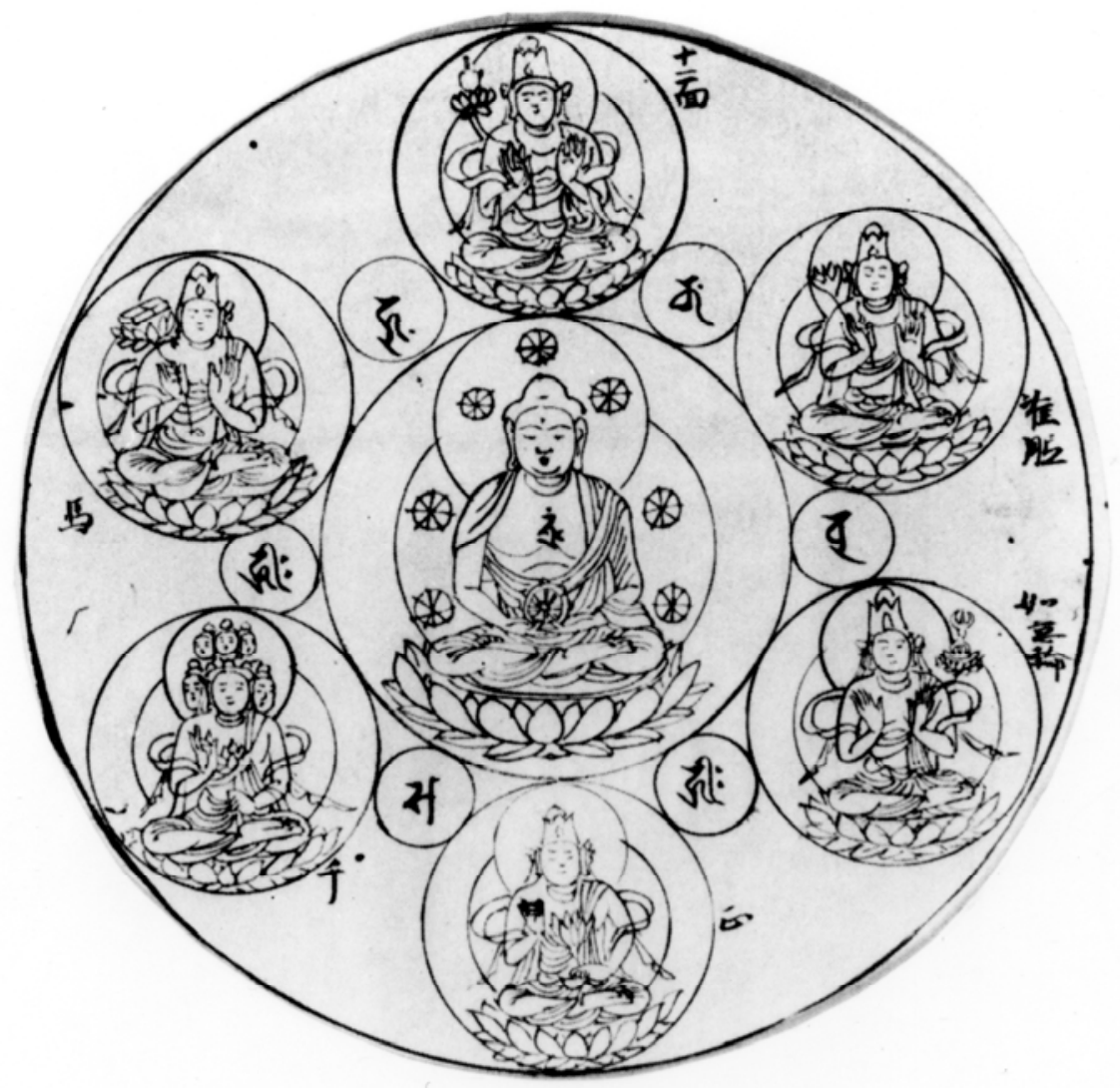

Culture and Cosmos 